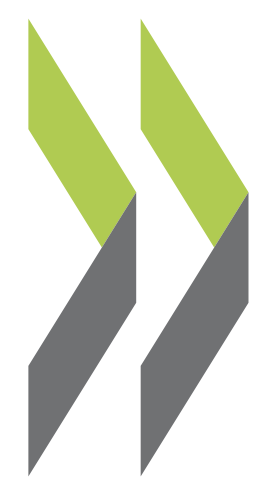

OECD Economics Department Working Papers No. 1665

Dennis Dlugosch,

\author{
Rauf Gönenç, \\ Yusuf Kenan Bağır, \\ Hüzeyfe Torun, \\ Eun Jung Kim
}

Unleashing the full potential of the Turkish business sector 


\section{ECONOMICS DEPARTMENT}

\section{UNLEASHING THE FULL POTENTIAL OF THE TURKISH BUSINESS SECTOR}

\section{ECONOMICS DEPARTMENT WORKING PAPERS No. 1665}

By Dennis Dlugosch, Rauf Gönenç, Yusuf Kenan Bağır, Hüzeyfe Torun and Eun Jung Kim

OECD Working Papers should not be reported as representing the official views of the OECD or of its member countries. The opinions expressed and arguments employed are those of the author(s).

Authorised for publication by Isabell Koske, Deputy Director, Country Studies Branch, Economics Department

All Economics Department Working Papers are available at ww.oecd.org/eco/workingpapers. 
OECD Working Papers should not be reported as representing the official views of the OECD or of its member countries. The opinions expressed and arguments employed are those of the author(s).

Working Papers describe preliminary results or research in progress by the author(s) and are published to stimulate discussion on a broad range of issues on which the OECD works.

Comments on Working Papers are welcomed, and may be sent to the Economics Department, OECD, 2 rue André-Pascal, 75775 Paris Cedex 16, France, or by e-mail to econ.contact@oecd.org.

All Economics Department Working Papers are available at www.oecd.org/eco/workingpapers.

This document and any map included herein are without prejudice to the status of or sovereignty over any territory, to the delimitation of international frontiers and boundaries and to the name of any territory, city or area.

The statistical data for Israel are supplied by and under the responsibility of the relevant Israeli authorities. The use of such data by the OECD is without prejudice to the status of the Golan Heights, East Jerusalem and Israeli settlements in the West Bank under the terms of international law.

Note by Turkey

The information in this document with reference to "Cyprus" relates to the southern part of the Island. There is no single authority representing both Turkish and Greek Cypriot people on the Island. Turkey recognises the Turkish Republic of Northern Cyprus (TRNC). Until a lasting and equitable solution is found within the context of the United Nations, Turkey shall preserve its position concerning the "Cyprus issue".

Note by all the European Union Member States of the OECD and the European Union

The Republic of Cyprus is recognised by all members of the United Nations with the exception of Turkey. The information in this document relates to the area under the effective control of the Government of the Republic of Cyprus.

๑) OECD (2021)

You can copy, download or print OECD content for your own use, and you can include excerpts from OECD publications, databases and multimedia products in your own documents, presentations, blogs, websites and teaching materials, provided that suitable acknowledgment of OECD as source and copyright owner is given. All requests for commercial use and translation rights should be submitted to PubRights@oecd.org. 


\section{Abstract/Résumé \\ Unleashing the full potential of the Turkish business sector}

Productivity in Turkey has been growing stronger than in most peer countries since 2010 but has slowed down. Despite a remarkably entrepreneurial population, business dynamism has also been less vigorous in recent years. This working paper discusses the factors behind this slowdown and analyses a wide range of structural policies that would help to revive productivity growth and unleash the full potential of the Turkish business sector. The elevated number of informal, semi-formal and fully formal forms constitutes a key impediment to higher growth and more high-quality jobs. Structural reforms that allow more flexibility in labour markets, more competition in product markets and major progress with the quality of governance would foster productivity growth, job creation but also boost the digital transformation. Streamlining and simplifying the complex system of regulations and government support schemes would prevent firms from clustering around eligibility thresholds and thus remove obstacles to the upscaling of firms.

This Working Paper relates to the 2021 OECD Economic Survey of Turkey (http://www.oecd.org/economy/turkey-economic-snapshot/)

Keywords: Turkey, productivity, informal labour markets, capital structure of the business sector, digitalization

JEL Classification: E22, E26, G30, G38, G21, J11, J21

\section{Libérer le potentiel de croissance du secteur des entreprises en Turquie}

La productivité en Turquie a augmenté plus fort que dans la plupart des pays comparables depuis 2010, mais a ralenti. Malgré une population remarquablement entrepreneuriale, le dynamisme des entreprises a été moins vigoureux ces dernières années. Ce document de travail examine les facteurs à l'origine de ce ralentissement et analyse un large éventail de politiques structurelles qui contribueraient à relancer la croissance de la productivité et à libérer tout le potentiel du secteur des entreprises turc. Le nombre élevé des différents types d'entreprises, en formes informelles, semi-formelles et pleinement formelles, constitue un obstacle majeur à une croissance plus forte et à des emplois de plus grande qualité. Des réformes structurelles qui permettraient plus de flexibilité sur le marché du travail, plus de concurrence sur le marchés des produits et des progrès majeurs dans la qualité de la gouvernance favoriseraient la croissance de la productivité, la création d'emplois mais aussi stimuleraient la transformation numérique. La rationalisation et la simplification du système complexe de réglementations et de régimes de soutien gouvernementaux empêcheraient les entreprises de se regrouper autour des seuils d'éligibilité et élimineraient les obstacles à la montée en gamme des entreprises.

Ce Document de travail a trait à l'Étude économique de l'OCDE du Turquie 2021 (http://www.oecd.org/fr/economie/turquie-en-un-coup-d-oeil/)

Mots Clefs: Turquie, productivité, marché du travail informel, structure du capital des entreprises, digitalisation

Classification JEL : E22, E26, G30, G38, G21, J11, J21 


\section{Table of contents}

\section{Unleashing the full potential of the Turkish business sector}

Growth of potential output has lost steam

Strengthening the business sector through more market-friendly reforms is key to more durable economic growth

Addressing the debt overhang 24

Tapping the benefits of increased adoption of digital technologies 33

Bibliography $\quad 38$

\section{Appendix 1. Unleashing the full potential of the Turkish business sector 44}

Measuring the speed of resource allocation $\quad 44$

Turkey has a wide range of business support measures in place $\quad 45$

The cost of capital of listed firms in Turkey $\quad 48$

\section{FIGURES}

Figure 1. Productivity growth has slowed

$\begin{array}{ll}\text { Figure 2. Educational enrolments have increased but quality has fallen behind } & 7 \\ \text { Figure 3. Qualification mismatch in OECD countries } & 8\end{array}$

Figure 4. The population displays high entrepreneurial spirit 9

Figure 5. Value added per technological intensity 11

Figure 6. Business dynamism is high but appears to slow down 12

Figure 7 . The speed at which resources flow to more productive firms varies across technological intensity and

firm size

Figure 8. Informal employment is more frequent in smaller firms

Figure 9. Larger more formal firms are, more productive 16

Figure 10. Employment per firm size 16

Figure 11. Product market regulations are restrictive 19

Figure 12. Statutory corporate tax rates are moderate $\quad 21$

Figure 13. Effective average and marginal tax rates for a hypothetical investment project 23

Figure 14. Leverage of manufacturing firms has increased over time 25

Figure 15. The recovery rate of the insolvency regime is low 27

Figure 16. Equity markets could play a larger role in financing investment 29

Figure 17. Cost of capital of listed firms is high

Figure 18. Turkish firms lag behind in the adoption of advanced ICT tools and activities 34

Figure 19. Digital skills and low numbers of high speed broadband subscriptions impede the adoption of
advanced digital technologies

\section{TABLES}

Table 1. Construction sectors account for a significant share in the economy 10

Table 2. Tax Status of Capital Companies and Sole Proprietorships 22

Table 3. SME stock market segments in selected emerging markets 31

Table 4. Thresholds for statutory audits in Turkey 32 


\title{
Unleashing the full potential of the Turkish business sector
}

\author{
By Dennis Dlugosch, Yusuf Kenan Bağır, Rauf Gönenç, Hüzeyfe Torun and Eun Jung Kim ${ }^{1}$
}

\section{Growth of potential output has lost steam}

The growth of potential output has declined in the period since the mid-2010s, reflecting both lower investment and to a lesser extent, a smaller contribution of total-factor productivity (Figure 1, Panel A). The growth rate of labour productivity was above most peer countries in recent years, but grew less quickly than over the 2010-2014 period (Figure 1, Panel B). This implies that Turkey has succeeded in catchingup but that the catch-up process may have slowed. The slowdown likely results from a combination of different factors, including structural impediments to competition and a policy environment that is less conducive to capacity-enhancing investment but also the maturing of the economy. Despite major progress in recent years, average levels of manufacturing investment, labour productivity, the share of R\&D expenditures in GDP, exported value added and skills of workers are relatively low compared to other OECD countries (see OECD, 2018a; KPI and further below), suggesting that a new wave of structural reforms is needed to reinvigorate a faster catch-up.

Lifting the growth rate of potential output requires more and higher quality investment. The productive capital stock has been growing fast (Figure 1, Panel A), though its level remains low in international comparison (OECD, 2018a). A significant expansion of lending for housing purchases and to construction firms has raised concerns about investment quality and allocation (OECD, 2018a). The share of total value added generated by construction sectors is relatively large as compared to the OECD and peer country average, though on a downward trend in recent years (see also Box 1). Equity financing in Turkey is expensive owing to less developed markets for risk capital. Less predictable macroeconomic policies than elsewhere but also competition from informal firms, which circumvent rigid regulations on labour and product markets by tapping the pool of informal workers, impede more FDI inflows. Inward FDI stocks are low in international comparisons suggesting that the business sectors are missing out on productivityenhancing knowledge spillovers.

Average skills level of the working age population, a key factor underpinning potential growth, remains low in international comparison (Figure 2). Turkey has made significant progress in secondary education enrolment rates (Figure 2, Panel B). It has now the longest compulsory education across OECD countries. Resource constraints imply that quality is bound to suffer following the fast increase in enrolment. Nevertheless, the low level of Turkey's PISA achievements underlines the need to increase the quality of education (Figure 2, Panel D). Moreover, despite progress in recent years only very few young Turks are

1. Dennis Dlugosch works as Economist on the Turkey desk of the Economics Department of the OECD and is the lead author of this paper. Rauf Gönenç is a Senior Economist and the Head of the Turkey Desk. Yusuf Kenan Bağır and Hüzeyfe Torun are both Economists working for the Central Bank of the Republic of Turkey. Eun-Jung Kim is the Statistician of the Turkey desk. The opinions expressed and arguments employed are those of the authors and should not be attributed to the OECD or its member countries. Special thanks go to Cevriye Aysoy for her support to this project, to Sebastian Barnes and Isabelle Joumard for their very helpful comments, to Cem Cebi for providing very good comments and inputs and to Michelle Ortiz and Heloise Wickramanayake for editorial assistance. 


\section{6 | ECO/WKP(2021)50}

enrolled in early childhood education (Figure 2, Panel A). The "Education Vision 2023" of the Ministry of National Education aims at boosting enrolment rates. This would entail a potentially large double dividend by increasing cognitive capabilities while promoting more female participation in the labour market.

Figure 1. Productivity growth has slowed

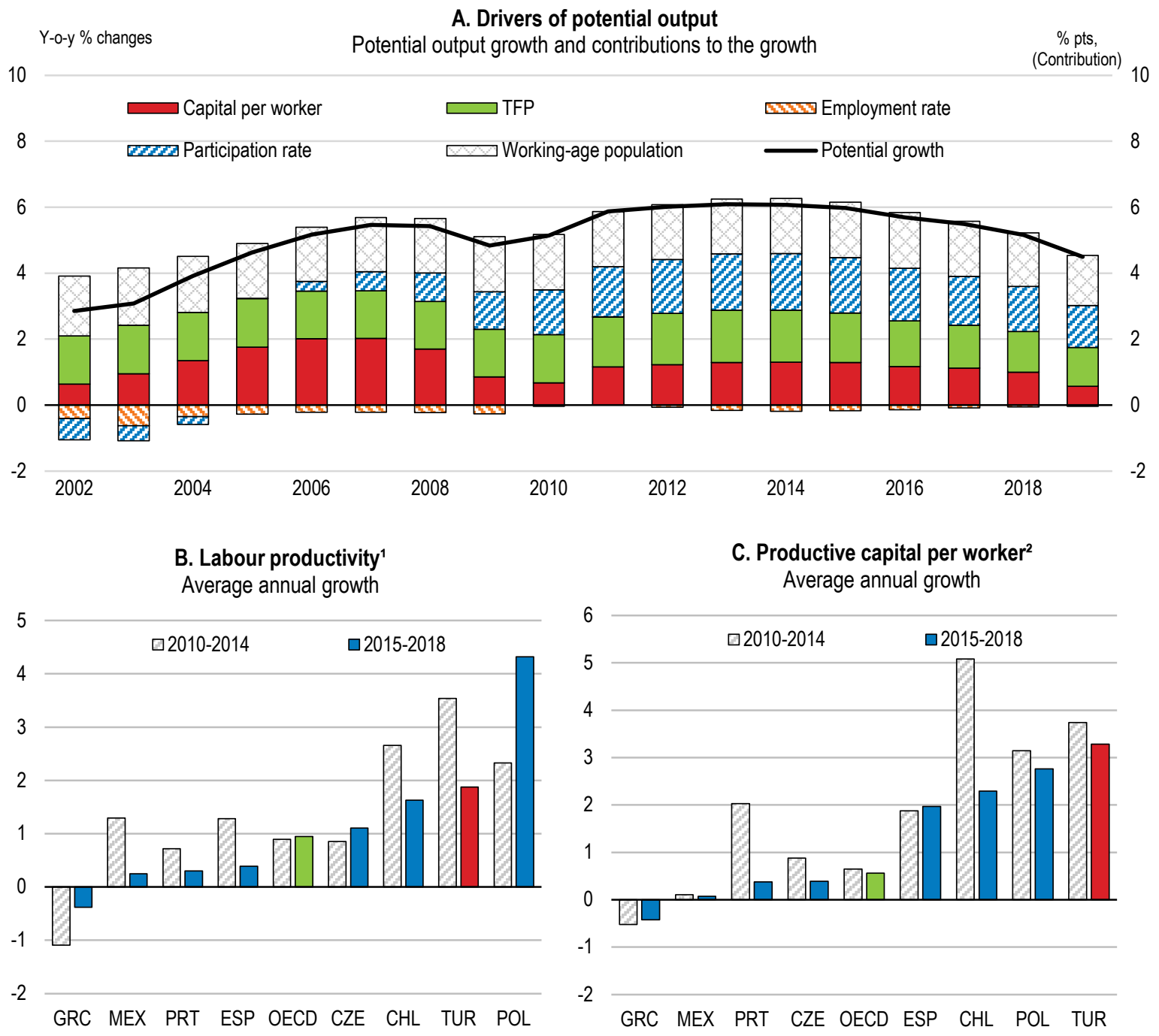

1. Real GDP per hours worked. Real GDP in constant 2015 PPPs, USD.

2. Real capital stock per worker.

Source: OECD calculations based on OECD (2020), OECD Economic Outlook: Statistics and Projections (database) and OECD Productivity Statistics (database).

Enrolment in tertiary education also increased and is now higher than in comparable OECD countries (Figure 2, Panel C). The heterogeneity of academic degree programmes without pre-defined dependable quality benchmarks for students, parents and employers constitutes a major challenge. Although Turkey has put in place large streams of vocational education, with as many as $32 \%$ of secondary students engaged in these programmes, their curricula and exposure to real-world work experience lag behind (Tarman and Yigit, 2010). 
Figure 2. Educational enrolments have increased but quality has fallen behind
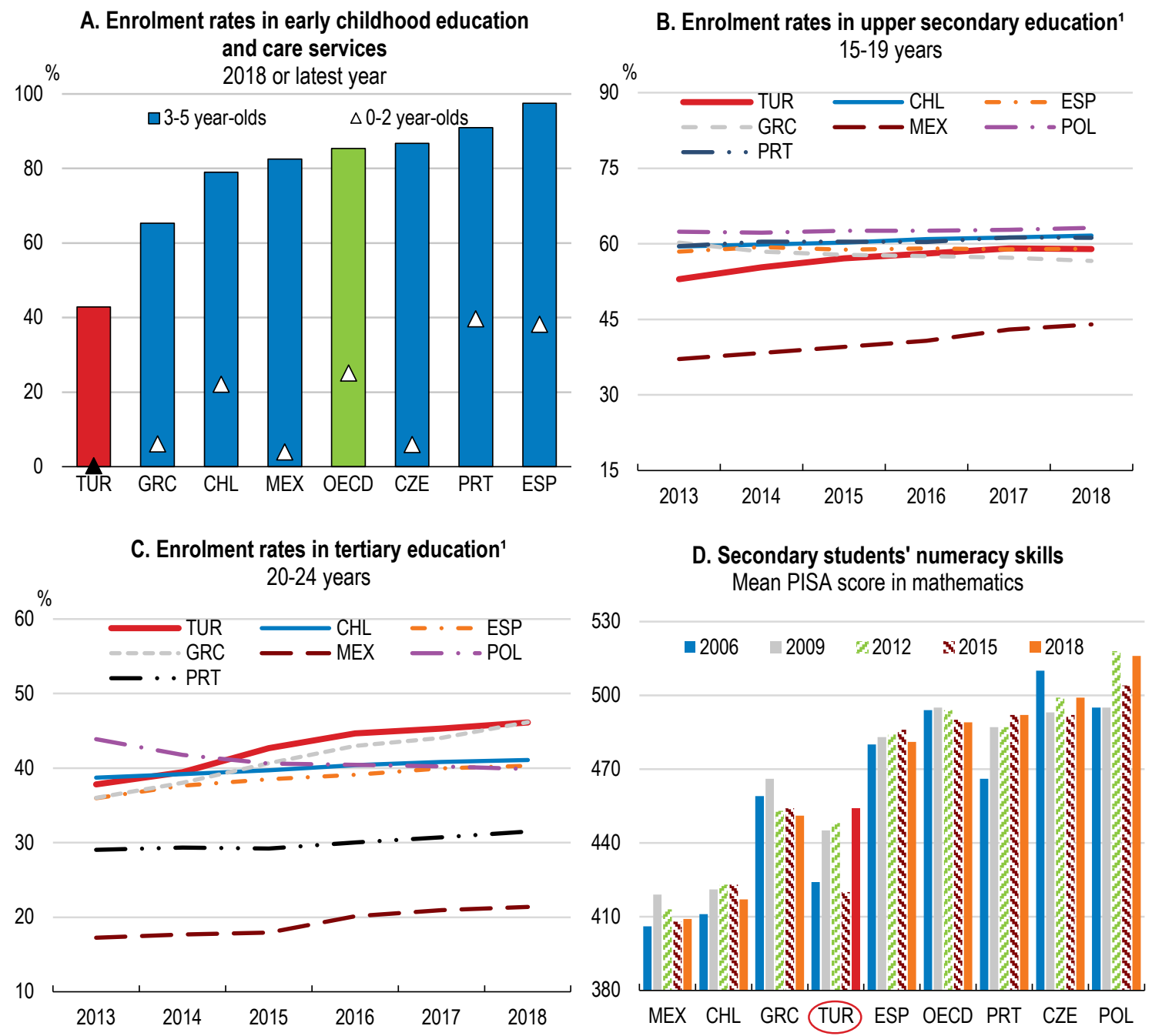

1. Based on the International Standard Classification of Education (ISCED) 2011. Upper secondary education refers to the level 3 and tertiary education refers to the levels 5-8.

Source: OECD (2020) Family Database (http://www.oecd.org/els/family/database.htm), OECD Education at a Glance database and OECD PISA databases.

OECD indicators suggest that Turkey has one of the highest degrees of qualification mismatch in the OECD area: $43 \%$ of the working population is found to be either over-qualified for their current job - $29 \%$ of workers have a level of qualification above the modal level of their occupation- or underqualified - $14 \%$ are in the reverse situation (Figure 3). The reported magnitude of over qualification is high as compared to other OECD countries. It may partly reflect the limited effective average qualifications of tertiary education graduates in international comparison. 


\section{Figure 3. Qualification mismatch in OECD countries}

\section{$15-64$ year-olds, 2016}

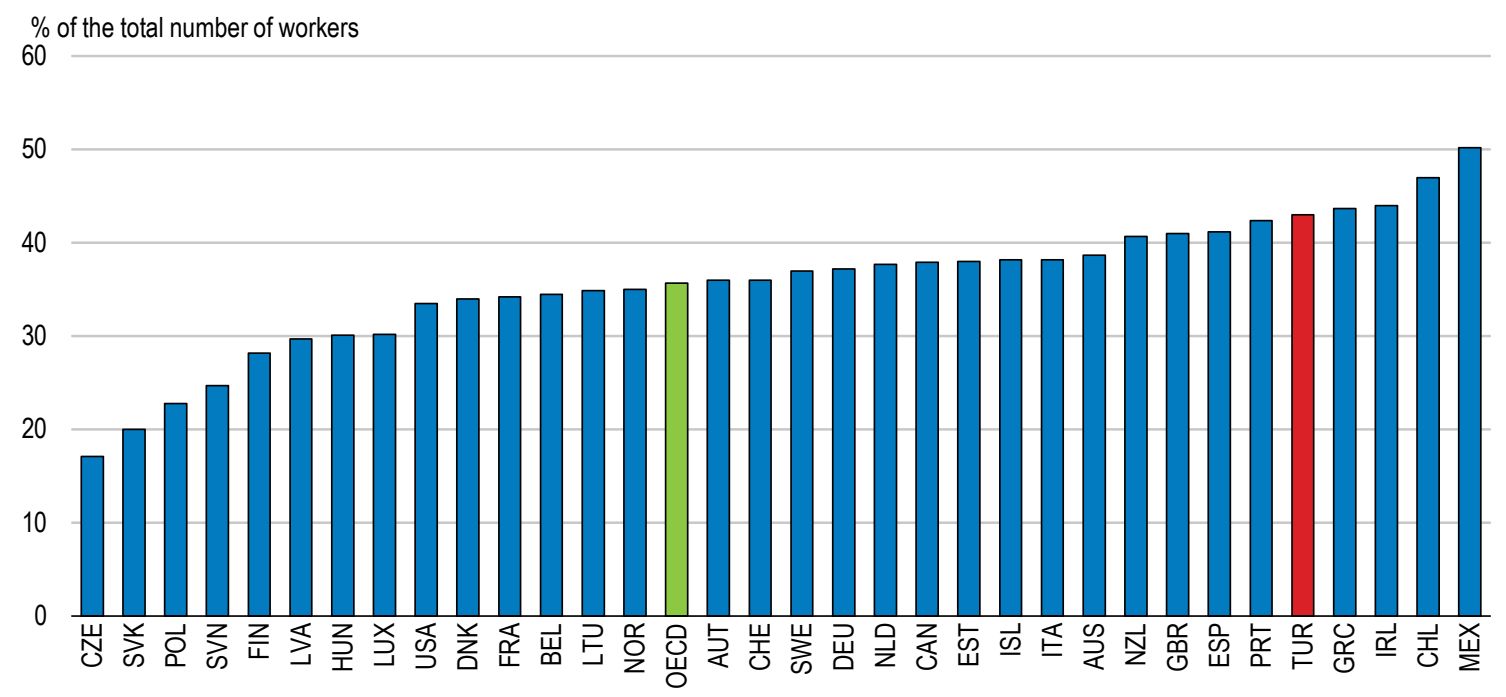

Note: Qualification mismatch arises when workers have an educational attainment that is higher (i.e. over-qualification) or lower (i.e. underqualification) than that required by their job.

Source: OECD (2020), OECD Skills for Jobs statistics (database).

Limited use of existing modest skills reflects the heterogeneity of firms. Low productivity and low quality firms have modest skill demands. This goes hand-in-hand with plain skill shortages in the modern formal sector. A 2019 survey found that one third of existing job positions in Turkish firms will need significant upskilling by 2030 (McKinsey, 2019). A similar survey identified Turkey as the $6^{\text {th }}$ among 43 reviewed counties for the severity of recruitment difficulties in the corporate sector (Manpower, 2019).

\section{Despite high entrepreneurial spirit, business dynamism has slowed down}

Turkey can rely on a young and very entrepreneurial population (Figure 4). Entrepreneurship goes far beyond subsistence entrepreneurs, who start a business for the sole purpose of providing employment for themselves and their families (Schoar, 2014), but also includes a high share of transformational entrepreneurs. Transformational entrepreneurs aim at creating large and expanding businesses and thus constitute the building block of a high degree of business dynamism. By contrast, subsistence entrepreneurs may trap resources in low efficiency activities that lack scale and the scope for productivity gains. The importance of entrepreneurship for economic growth in Turkey is also acknowledged in the recently published New Economic Program. A key goal is to increase the effectiveness of the entrepreneurship ecosystem by identifying any problems that may currently impede the uptake of entrepreneurial activity. Further, numerous policy initiatives like the "Young Entrepreneur Incentive", which exempt young self-employed from social security contributions for one year under certain conditions, continue to underpin entrepreneurship across young people.

While Turkey's population is still very young, the share of people aged 15-24 is projected to decrease slowly over the coming decades. According to the Turkish Statistical Institute, the share of people aged $15-24$ is projected to be around $12 \%$ in 2060 , while it stood at $16 \%$ in 2019 . This underlines the urgent need for decisive structural reforms to reinvigorate business dynamism and productivity growth to make the most of its young population.

Higher management quality would help Turkey to reap greater benefits from its entrepreneurial population. Survey indicators suggests that the quality of management lags behind peer countries (Del Carpio and 
Taskin, 2019). Good managers make better use of resources, in particular regarding workers' skills, thereby boosting productivity (Bloom and van Reenen, 2010).

Figure 4. The population displays high entrepreneurial spirit

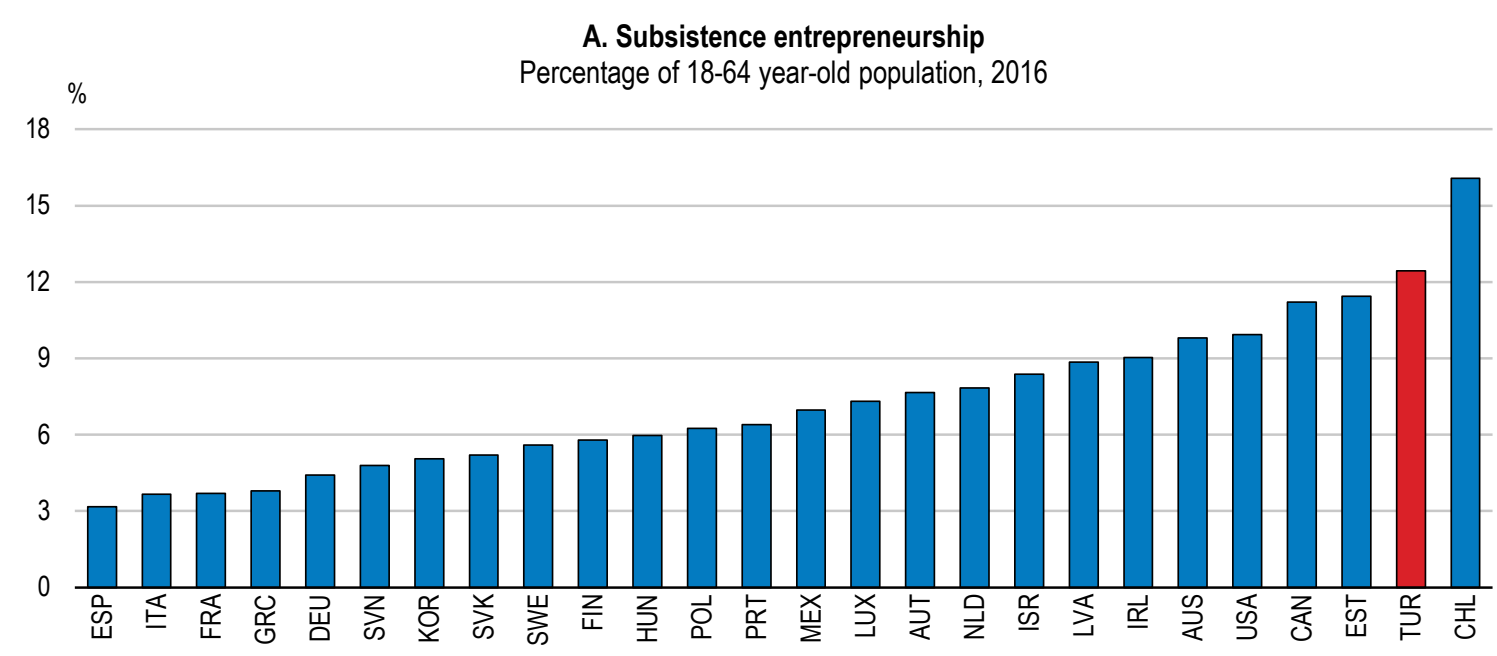

B. Transformational entrepreneurship

$\% \quad$ Percentage of 18-64 year-old population, 2016

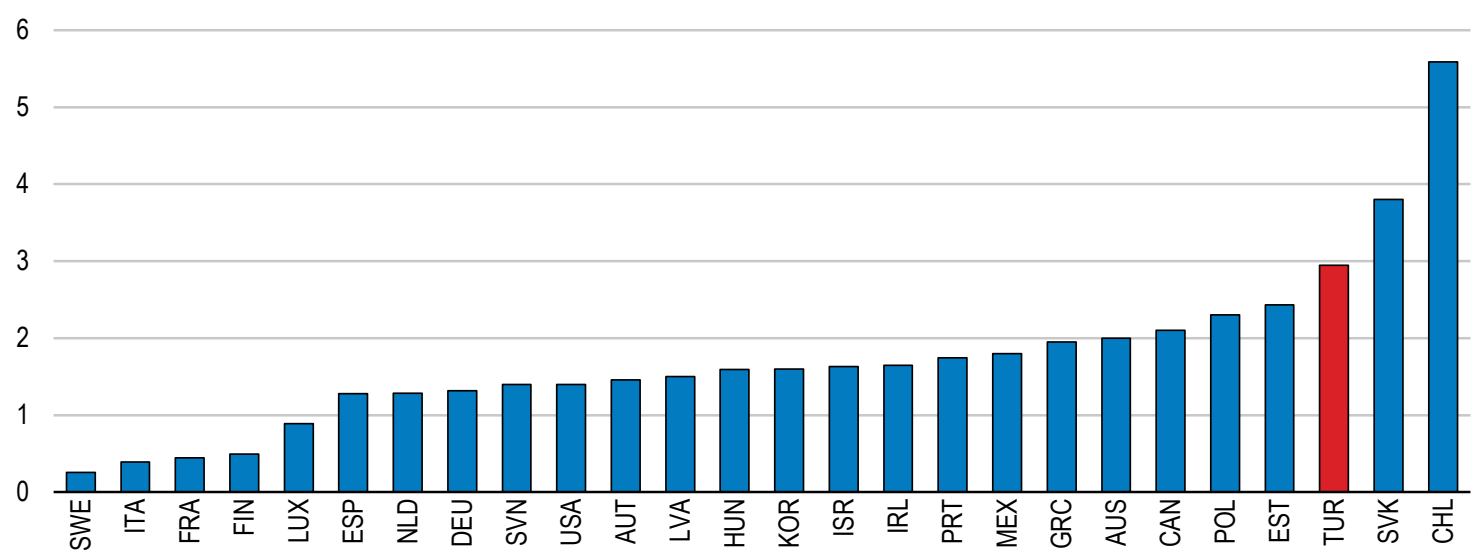

Source: Global Entrepreneurship Monitor (2019). 


\section{Box 1. Industry composition and breakdown by technological intensity of the business sector}

\section{Agriculture and construction account for more value added than elsewhere}

Turkish agricultural sectors stand out for their large share in total value added compared to peer countries (Table 1). Furthermore, the contribution of construction to aggregate value added is also relatively high as compared to the OECD and peer country average, reflecting elevated demand for modernised infrastructure and housing, significant internal migration across regions and high earthquake risks (OECD, 2018a). The significant increase in the share of value added generated in construction in the last two decades may also result, at least partly, from an unsustainable housing boom. In recent years, the importance of construction sectors has decreased, notably in the aftermath of the 2018 currency crisis. The share of manufacturing sectors rose and stands now at around $21 \%$ of total value added, above the respective share in the peer countries and OECD average. The contribution of business services is lower than in the OECD average.

\section{Table 1. Construction sectors account for a significant share in the economy}

\begin{tabular}{l|c|c|c|c|c}
\hline \multicolumn{1}{c|}{ Sector } & Turkey & $\begin{array}{c}\text { Peer country } \\
\text { average }\end{array}$ & $\begin{array}{c}\text { OECD } \\
\text { average }\end{array}$ & $\begin{array}{c}\text { OECD } \\
\text { minimum }\end{array}$ & $\begin{array}{c}\text { OECD } \\
\text { Maximum }\end{array}$ \\
\hline $\begin{array}{l}\text { Agriculture, forestry and } \\
\text { fishing }\end{array}$ & $6.4 \%$ & $2.9 \%$ & $2.4 \%$ & $0.3 \%$ & $6.9 \%$ \\
\hline Mining and quarrying & $1.1 \%$ & $3.0 \%$ & $1.4 \%$ & $0.1 \%$ & $10.8 \%$ \\
\hline Manufacturing & $21.2 \%$ & $16.0 \%$ & $17.1 \%$ & $5.7 \%$ & $34.6 \%$ \\
\hline Utilities & $2.5 \%$ & $3.5 \%$ & $2.8 \%$ & $1.3 \%$ & $4.2 \%$ \\
\hline Construction & $7.9 \%$ & $6.5 \%$ & $6.2 \%$ & $2.8 \%$ & $8.0 \%$ \\
\hline Business services & $45.6 \%$ & $50.1 \%$ & $50.8 \%$ & $45.4 \%$ & $68.7 \%$ \\
\hline Public services & $14.8 \%$ & $18.2 \%$ & $19.7 \%$ & $12.0 \%$ & $25.1 \%$ \\
\hline
\end{tabular}

Note: Shares based on gross volumes of value added in 2018. Peer country and OECD averages are unweighted. Peer countries are Spain, Portugal, Greece, Czech Republic, Poland, Chile and Mexico.

Source: OECD Annual National Accounts Database, Table 6A.

\section{Low- to medium-low technological intensity prevail in manufacturing}

Manufacturing accounts for about one fifth of total value added, in line with peer countries and slightly above the OECD average. Within manufacturing, low-technology and medium-low-technology sectors account for around $70 \%$ of total value added (Figure 5 , Panel A), well above the OECD average. This share only changed slightly over the past decade (Figure 5 , Panel B). This extends to exported goods. While the share of exports of medium-to-high and high-technology manufacturing goods in total exports increased significantly since 2010 , the overall technological sophistication of exports, as measured by the economic complexity index, lags behind other OECD countries (OECD, 2018a). 


\section{Figure 5. Value added per technological intensity}

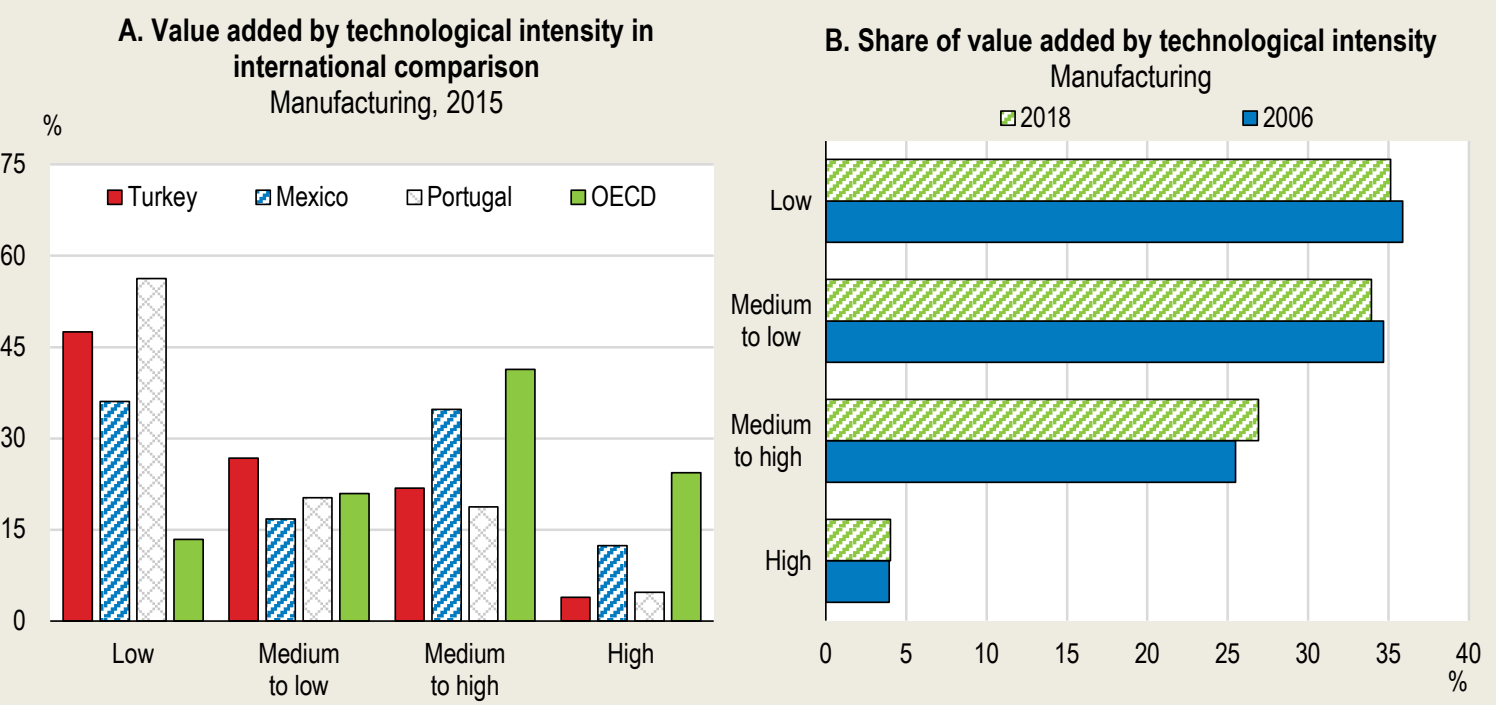

1. Based on firm-level balance sheet data. Value added is defined as the sum of the total labour costs and the operating profits. Real value added is obtained by deflating nominal value added with the GDP deflator for manufacturing sectors.

Source: Central Bank of the Republic of Turkey (2020), Entrepreneur Information System (EIS).

The high degree of entrepreneurial spirit coincides with high entry and exit rates (Figure 6, Panel A and B). Around $30 \%$ of all enterprises in manufacturing sectors are start-ups younger than two year old. Their share in business service sectors is even higher. Entry rates are significantly above the rates in peer countries and the OECD average. Moreover, new jobs generated by start-ups account for around $7 \%$ of total employment, significantly above other OECD countries. This makes Turkey's business sector one of the most dynamic among OECD countries. However, firms appear to cluster around the size threshold used to differ between small-, medium- and large companies (Özlale and Polat, 2019), indicating that impediments to the upscaling of firms tend to limit the benefits of a highly dynamic business sector. 


\section{Figure 6. Business dynamism is high but appears to slow down}

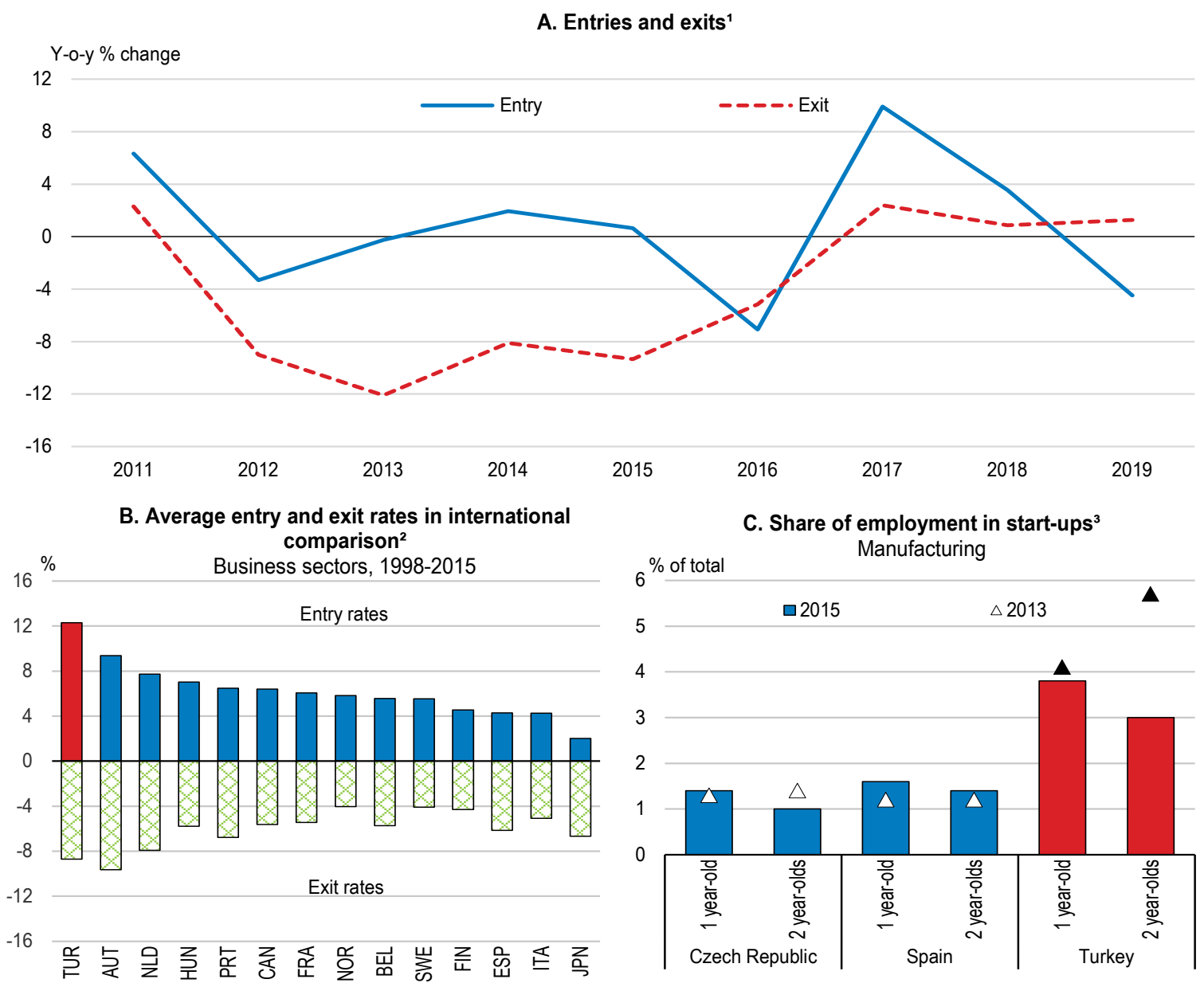

1. Based on Company Establishment and Liquidation Statistics in the Union of chambers and commodity exchanges of Turkey.

2. Panel $B$ for each country shows unweighted averages of entry and exit rates across STAN 38 industries and available years for the period 1998-2015. Figures are based on manufacturing and non-financial market services, with the exception of Japan where only manufacturing data are available. Self-employment and the Coke and Real estate sectors are excluded. A coverage table is available in: Calvino, F. and C. Criscuolo (2019), "Business Dynamics and Digitalisation", OECD Science, Technology and Industry Policy Papers 62.

3. Start-ups are defined as new firms which are not older than 2 years.

Source: OECD (2020), OECD Structural Analysis (STAN) Database and OECD calculations based on the Union of chambers and commodity exchanges of Turkey. OECD (2019), "Measuring the Digital Transformation: A Roadmap for the Future".

The dynamism of the business sector appears to have fallen (Figure 6, Panel C; see also Acemoğlu and Üçer, 2019; Özlale and Polat, 2019; Akçigit et al., 2020). The share of employment in starts-ups both in manufacturing and business service sectors has decreased. While average growth of new entrants was around $1.1 \%$ in the $2010-2014$ period, it slowed down to around $0.3 \%$ in the $2015-2019$ period, again from a comparatively high level. On the one hand, this may result -at least partly- from slow economic growth in 2016 and 2018. On the other hand, the lower level of entry rates may also reflect the maturing of the economy or other factors common across many countries, such as the potential for scaling up through employing software-based solutions instead of hiring more labour (Decker et al., 2016). Exit rates increased in recent years. The downward trend in new entries is worrying for Turkey, given the crucial importance of young firms in generating new jobs (e.g. Criscuolo, Gal and Menon, 2014; Atiyas et al., 2017; Özlale and Polat, 2019). Recent policy initiatives like the "2023 Industry and Technology Strategy" of the Ministry of Industry and Technology which intend to reinvigorate the entrepreneurship ecosystem by easing the registration of start-ups and closing of failing businesses are welcome (link). However, they need to be 
accompanied with measures that address rigid regulations on labour market and an overly complex business subsidy and corporate tax system.

Efficiency of resource allocation constitutes a third key factor that underpins aggregate productivity growth. Even in the absence of any productivity enhancing improvements within firms, allocating labour and capital to more productive firms can foster productivity growth. Similar to productivity and business dynamism, the allocative efficiency of the Turkish economy, appears to have declined (Nguyen et al., 2017; World Bank, 2019a).

The speed at which labour flows to more productive manufacturing firms varies substantially across firm sizes and sectors in Turkey (Figure 7). New firm-level analysis performed for this Survey uses data on Turkish manufacturing firms (see Box 2) and a standard methodology (Decker et al., 2018; OECD, 2018b). It computes an indicator of allocative efficiency based on the responsiveness of employment growth to the level of labour productivity. This indicator builds on the idea that resources should flow to the most productive firms. The speed at which resources flow to more productive firms is significantly higher for smaller firms and new manufacturers. A similar but less marked pattern holds for manufacturing sectors with low and low-to-medium technological intensity. This supports the view that smaller firms and firms in less sophisticated technological sectors in Turkey find it easier to upscale and attract labour, likely by circumventing labour markets regulations and by tapping the pool of informal workers.

Figure 7. The speed at which resources flow to more productive firms varies across technological intensity and firm size

Allocative efficiency, manufacturing

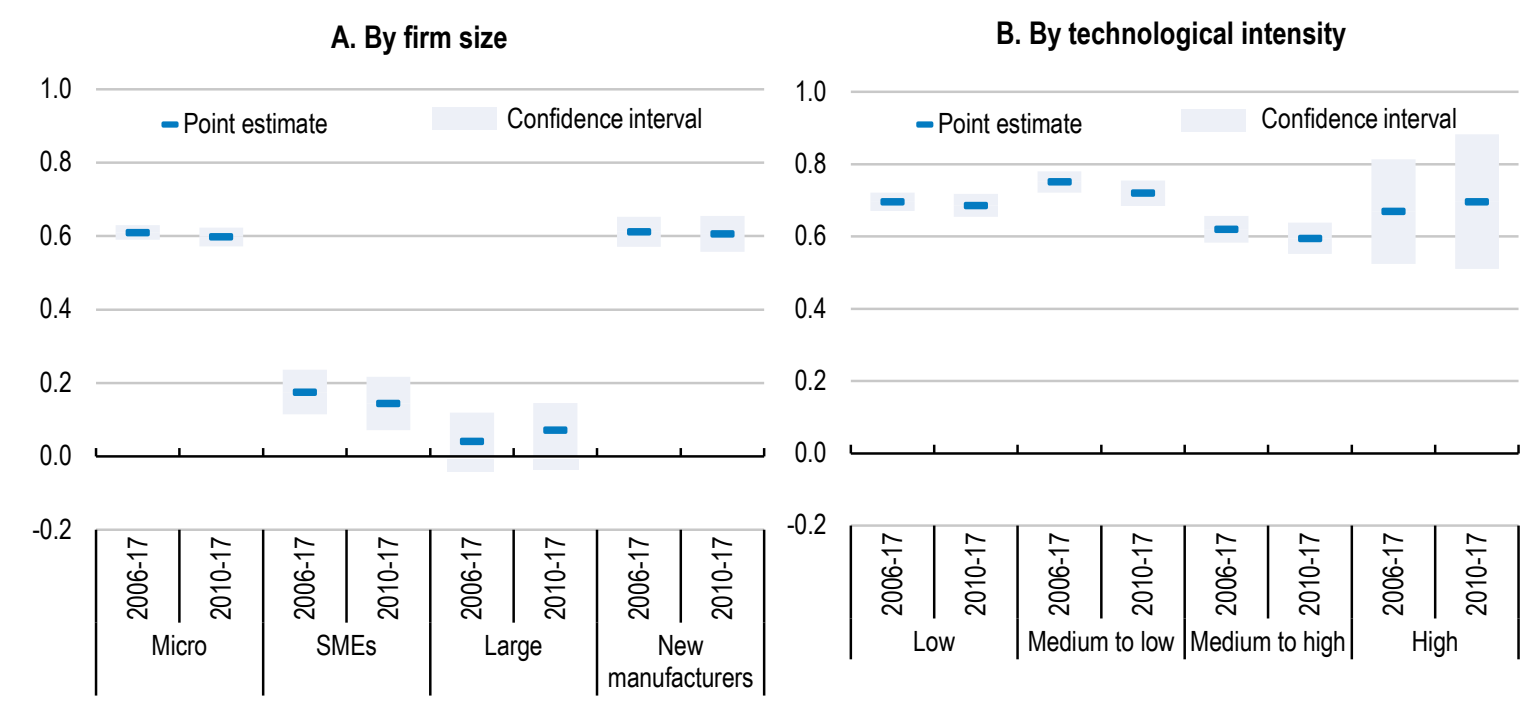

Note: The bars depict the estimated coefficients and $95 \%$ confidence intervals of a reduced-form canonical model of firm dynamics. Employment growth is regressed on lagged labour productivity, while controlling for other firm-specific variables and sector-year fixed effects. See Box 1.5 for more details on the employed variables and estimation method.

Source: OECD calculations based on Turkish firm-level data. 


\section{Box 2. Firm-level data from the Entrepreneur Information System Database}

This paper uses data from the Entrepreneur Information System Database (EIS), a Turkish dataset of firm-level balance sheet items. It was analysed in cooperation with the Structural Economic Research Department of the Central Bank of the Republic of Turkey and is not publicly available. The EIS dataset consists of firm-level data from eight administrative sources, put together by the General Directorate for Strategic Researches and Productivity of the Ministry of Industry and Technology.

The data used in this paper is a subset of the full EIS dataset and includes information on manufacturing sectors only. The sample consists of firms with detailed balance sheets and income statements reported to the Revenue Administration of the Ministry of Treasury and Finance. Micro-sized sole proprietorships, which submit only simplified income statements, were excluded. More details on the EIS dataset can be found in OECD (2018a) and Özlale and Polat (2019).

Firm-level labour productivity is calculated as real value added over total employment. Value added is computed as the sum of total labour costs and operating profits, deflated by the GDP deflator for manufacturing sectors (base year is 2017). The total number of employees is the average of the reported number of employees during the $3^{\text {rd }}, 6^{\text {th }}, 9^{\text {th }}$ and $12^{\text {th }}$ months of the year from the Social Security Administration. Firms with average employees less than one are dropped.

The firm-level data is cleaned for large outliers by dropping observations in $t$ and $t-1$ if a firm experienced an extreme rise or drop in its employee numbers.

The aggregate statistics on various indicators in this paper based on EIS data are calculated with unweighted averages.

\section{Strengthening the business sector through more market-friendly reforms is key to more durable economic growth}

\section{The need for more formalisation}

The fragmentation of the business sector in informal, semi-formal, fully-formal firms and the so-called "young startups" (see Box 3 for a definition of informality), constitutes a major obstacle to higher productivity. While the share of informal and semi-formal firms is high across the whole economy, informality is particularly pronounced in smaller firms (Figure 8). Whereas more than $50 \%$ of micro-firms' employees are unregistered with the social security system, less than $10 \%$ of total employment of large firms is informal. At the same time, small- and medium-sized firms account for the majority of total employment (see also Box 3). 


\section{Figure 8. Informal employment is more frequent in smaller firms}

Share of unregistered employment by firm size

A. Total

$\%$ of total, by firm size
B. Non-agriculture

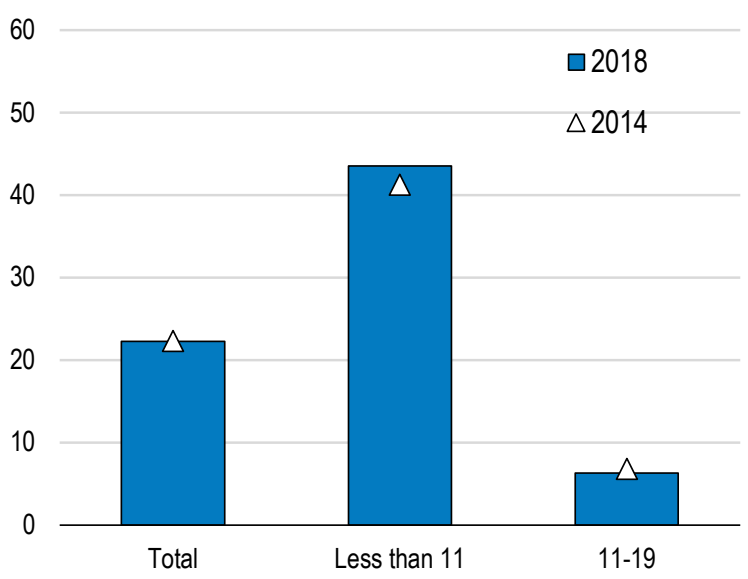

Notes: Based on household labour force survey results.

Source: TurkStat (2019).

The prevalence of informal and semi-formal activities in smaller firms parallels stark differences in productivity across different firm sizes. The productivity gap between small- and medium-sized firms in Turkish manufacturing sectors is among the largest across peer countries (Figure 9, Panel A). There is considerable potential for scale-economy enhancing mergers and co-operation opportunities between firms. Further, the gap between small- and medium-sized firms and their large counterparts increased over time (Figure 9, Panel B). The so-called "young startups", which are enterprises founded after the year 2000 operating in medium-high to high technological sectors, tend to have similar levels of productivity as large firms, suggesting that Turkey has fruitful soil to improve the overall technological intensity of its manufacturing sectors.

The low average productivity of enterprises results from a combination of factors. The average level of productive capital per worker and skills level, including that of owners and managers, lag behind other OECD countries despite strong investment growth and improvements in enrolment rates on secondary and tertiary education (see also KPI; OECD, 2018a). On average, Turkish firms are also less engaged in exporting activities and exporting firms mainly produce goods that are consumed as final goods elsewhere (OECD, 2016). Together with the comparatively low levels of FDI inflows, Turkish firms are, on average, less exposed to productivity inducing foreign competition and learning-by-doing and productivity spillovers from parent firms. 
Figure 9. Larger more formal firms are, more productive
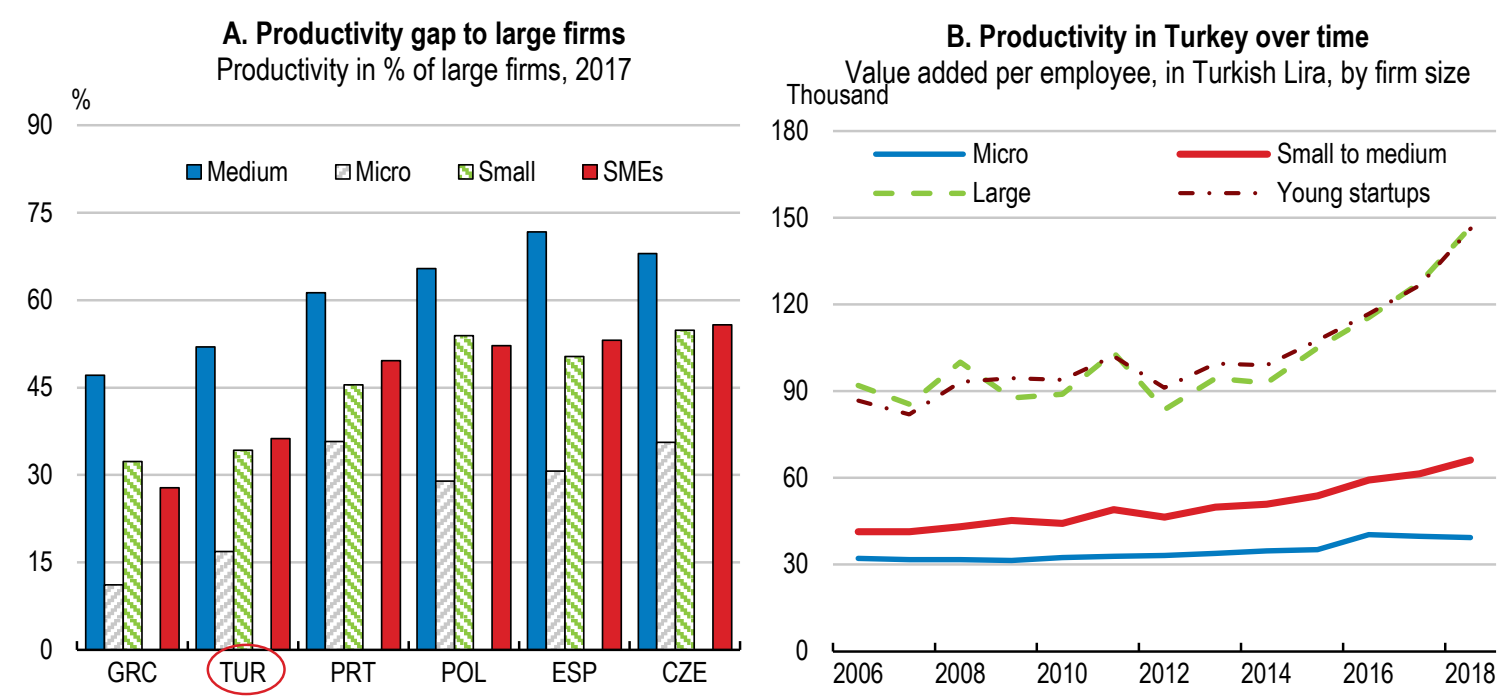

Source: World Bank and the Central Bank of the Republic of Turkey.

\section{Box 3. Overcoming fragmentation in the business sector}

\section{Micro- and small-scaled firms dominate the business sector}

As of 2020 and across all business sectors, the vast majority of the 1.9 million enterprises in Turkey have fewer than 10 employees, i.e. are micro-enterprises. Around $98 \%$ of all manufacturing firms have fewer than 50 employees, i.e. constitute micro- or small-sized firms following the definition of SMEs of the European Commission. On the contrary, only around $0.5 \%$ of manufacturing firms have more than 250 employees, and only $2.5 \%$ of all firms are medium-sized, i.e. have between 50 and 249 employees.

\section{Figure 10. Employment per firm size}

Contribution of SMEs to employment, by sector, 2017

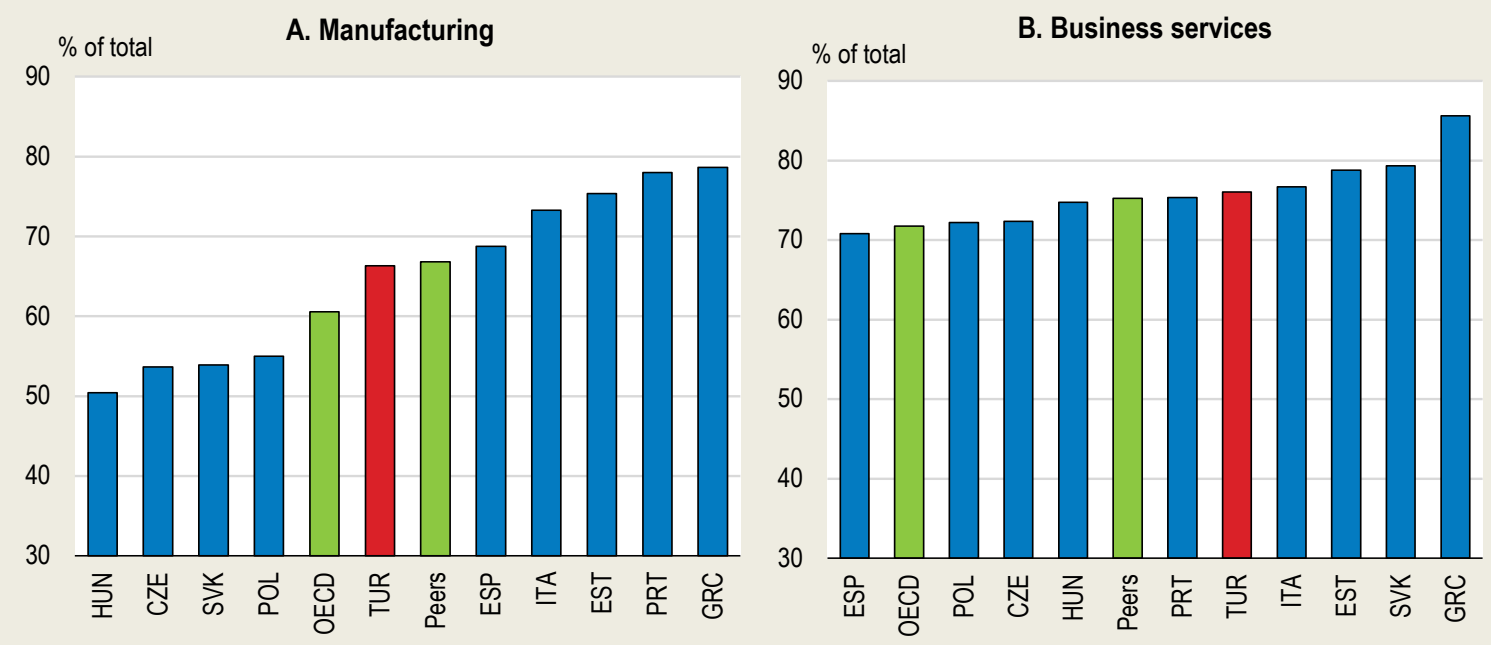

Note: Business services except financial and insurance activities. Peer countries refer to the Czech Republic, Greece, Poland, Portugal and Spain. Unweighted average.

Source: OECD (2020), OECD Structural and Demographic Business Statistics (SDBS). 
Broadly speaking, there are four types of firms depending on their degree of formalisation (see also OECD, 2016 and OECD, 2018a):

- Very small informal businesses employ $60 \%$ of all informal workers in the Turkish economy. The share of informal workers is much less in larger and more formal firms. The agricultural sector consists of up to $80 \%$ of small informal businesses. Only around $20 \%$ of employees are considered unregistered in manufacturing and other sectors.

- Medium-sized family firms: Often started as a small informal business, they contributed to Turkey's industrialisation through their steady growth and improvements in technical, financial and managerial skills (OECD, 2018a). They are usually larger than small informal firms, and make more but still incomplete use of registered workers. They may also be underreporting their wages and some of their financial information. Many medium-sized family firms are in this sense semiinformal.

- Large, fully formalized firms: They constitute the main pillar of the formal economy in the Turkish business sector. In 2020, the Turkish total business economy, i.e. all private sectors excluding finance and insurance sectors, consisted of 32183 large enterprises. Large, fully formalized firms made up around $25 \%$ of total employment and roughly $50 \%$ of value added of the total business economy.

- Young startups: The so-called young startups are firms born after the year 2000 and operate in medium-high and high-technology sectors. They constitute a relatively small but expanding part of the Turkish economy. They benefit from various government measures to boost the domestic start-up scene, in particular in high-technology sectors (OECD, 2018a). Young start-ups in hightechnology activities cluster around university technoparks. While they remain peripheral in quantitative terms, these firms have started to contribute to technology diffusion.

Diminishing productivity gaps across informal, semi-formal and fully formal business activities would help to reinvigorate regional convergence. While the provinces with the lowest incomes per capital grew more rapidly than other regions in the 2000s, regional convergence appears to have stalled in recent years (See Figure 20 above, Panels A and B). The geographical disparities across the 81 provinces mirrors differences in human capital but also in job quality and firms' productivity levels. Provinces with lower incomes tend to have higher shares of unregistered employment (see Figure 1.20 in OECD, 2021). Thus regulatory reforms that tackle informality, e.g. by reducing the costs of operating in full compliance with law, would help to lift productivity growth in lagging region and spur regional convergence.

\section{A complex system of regulations entrenches the fragmentation of the business sector}

Overly stringent regulations on product and labour markets (see also KPI) and a complex business support and taxation system make it difficult for firms to grow and move to the formal sector. Empirical evidence suggests that firms in Turkey tend to stay within certain size categories. These size categories coincide with the size classification of the government related to regulations and subsidies (Özlale and Polat, 2019). The probability of a micro-sized manufacturing firm ( 3 to 9 employees) to move to the small-sized firm category (10 to 19 employees) amounts to $10 \%$ over a five-year horizon. However, a firm with 10 to 19 employees grows in $20 \%$ of the cases into a firm with 20 to 49 firms (Özlale and Polat, 2019). A similar difference pertains to the other size thresholds as well. While informal and semi-formal firms can tap flexible employment forms and thereby succeed in competing with more formal firms, in particular in labourintensive sectors, fully law-abiding and financially transparent firms have much less flexibility due to Turkey's relative rigid employment regulations (OECD, 2016).

Investment and job creation are held back by stringent product market rules (Figure 11). These regulations undermine the entry of new firms in the fully formal sector, but also impedes a more efficient allocation of resources, given that incumbents are shielded from healthy competition, thereby allowing less productive 
firms to grow (Adalet McGowan, Andrews and Millot, 2018; Gamberoni, Giordana, and Lopez-Garcia, 2016). OECD's updated product market regulation (PMR) indicators (OECD, 2020, forthcoming) suggest that starting-up a new firm is more burdensome as in most other OECD countries. Furthermore, the government commands the largest operators in key network industries, and price regulations are more restrictive. Barriers to international value chain integration are among the highest (OECD, 2020, forthcoming). These restrictions are costly for formal businesses and keep their investment and productivity growth below potential.

A Committee for the Improvement of the Investment Environment (YOIKK) has been addressing reform needs in product markets for a number of years. It has representatives from public and private sectors and focus de facto on improving Turkey's position in World Bank's Doing Business Indicators. After a number of regulatory revisions recommended by this Committee, Turkey considerably improved its ranking in these indicators. However, the reform agenda should not be dominated by scoring and ranking considerations. The gap between OECD and World Bank indicators invites a wide-ranging reform strategy.

There are a number of priorities to improve the functioning of product markets:

- Product markets are more open to competition in goods than in services, owing partly to the Customs Union agreement with the EU. The agreement fostered direct exposure to trade in markets for goods, as well as to domestic competition, thanks to its competition policy provisions.

- Services offer a contrasted picture. Small-size services are competitive and vibrant. Larger and more sophisticated professional and network services are more sheltered from domestic and international competition than in comparable countries. There is significant scope for additional removal of regulatory barriers, in particular in digital services (Figure 11). After a decision of the Competition Authority of Turkey followed by an approving court decision on anti-competitive practices, Booking.com ceased their operations in Turkey. Uber, another cross-border service provider, discontinued their activities in Turkey due to regulatory requirements. The impact on competition of these requirements should be re-evaluated by the Competition Policy Authority. Turkish authorities have expressed reservations regarding the comprehensiveness of the STRI index for the Turkish economy.

- Agriculture and food products suffer from many structural impediments to competition, which hamper productivity (link). The sector represents nearly $20 \%$ of total employment and food products make up $23 \%$ of the consumer basket. Distribution channels are not fluid and the wedge between producer and consumer prices is growing: between 2010-2018, agricultural producer prices increased by $77 \%$, much less than the $122 \%$ increase in processed food prices.

Public procurement has expanded in the past decade. It remains dominated by construction services and is subject to several de jure and de facto impediments to competition. Studies on Turkey's public procurement markets emphasise the efficiency losses, the additional fiscal costs and the political economy distortions arising from reduced competition (Gürakar, 2016; Çetinkayac, 2014; Çetinkayac and Eroğlu, 2020). Risks include entrenchment of politically-connected firms, with negative impacts on public integrity (Faccio, 2006).

The modernisation of the Customs Union in collaboration with EU partners, currently on the agenda, can further advance competition and efficiency gains in the formal sector. It may accelerate structural changes in agri-food sectors, in network services and in public procurement. Productivity gains comparable to the gains achieved in manufacturing following the establishment of the Customs Union agreement may be expected to extend to these important sectors (Taymaz and Yilmaz, 2007; World Bank, 2014). 
Figure 11. Product market regulations are restrictive

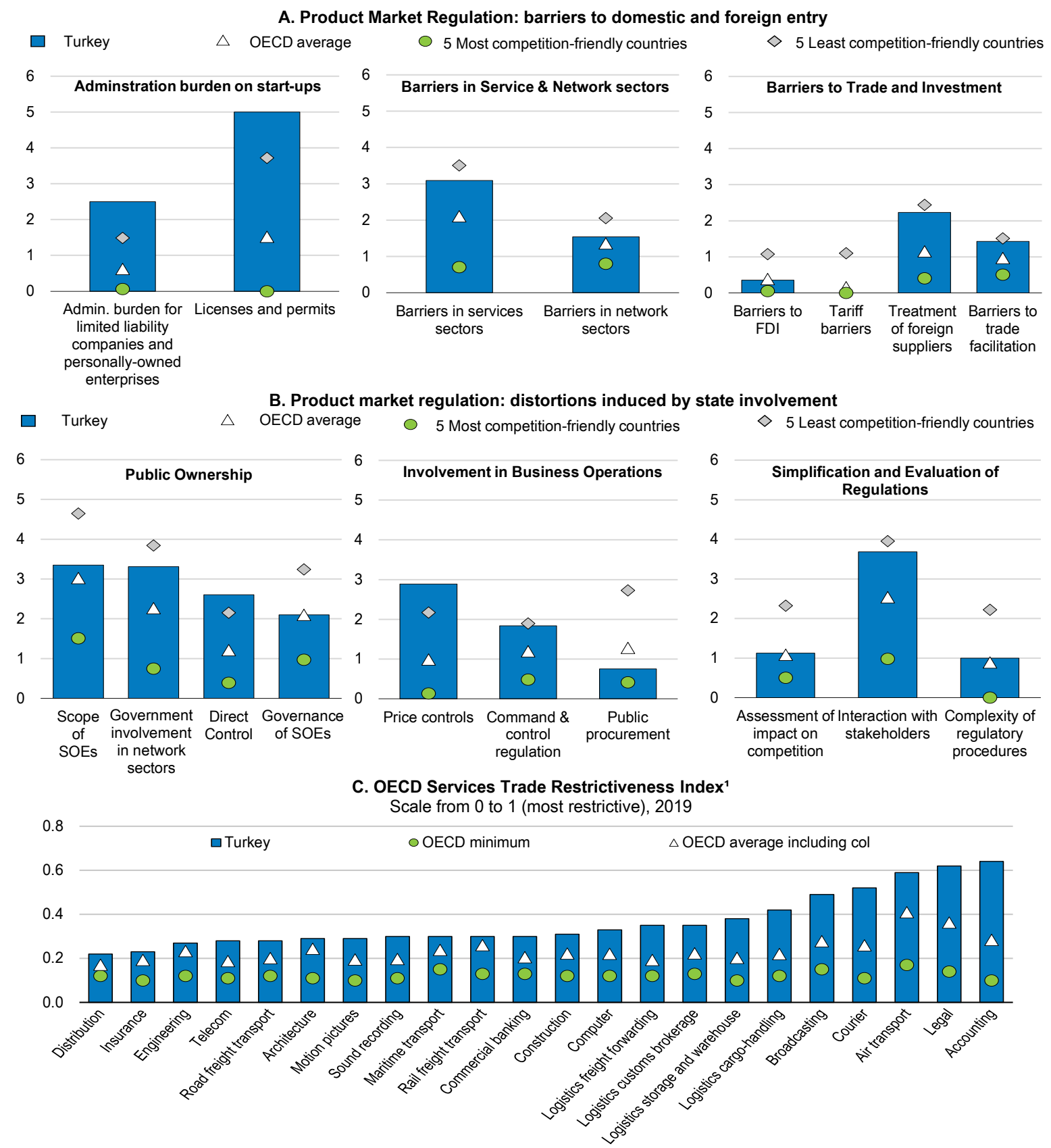

1. The index includes regulatory transparency, barriers to competition, other discriminatory measures, restrictions on movement of people and restrictions on foreign entry. It is calculated on the basis of the Service Trade Restrictions Index (STRI) regulatory database over the 37 OECD Members, Brazil, China, Costa Rica India, Indonesia, Malaysia, Russia, Thailand and South Africa. The STRI database records measures on a most-favoured-nations basis. Preferential trade agreements are not taken into account. Air transport and road freight cover only commercial establishment (with accompanying movement of people).

Source: OECD 2018 PMR database and OECD (2020), "Service Trade Restrictions Index by services sector" in OECD Industry and Services Statistics (database).

\section{Streamlining business incentives would sharpen their effectiveness}

Turkey has expanded its business support system over the recent years. According to the $11^{\text {th }}$ National Development Plan for the period 2019-23, the support system aims at, inter alia, promoting exports and 
internationalisation, fostering innovation and easing access to finance for firms of all sizes. The support system provides incentives to invest in specific regions and sectors, including through deductions or refunds on taxes, reduced loan rates for eligible new investments and deductions on social security contributions for any jobs created by new investments. An overview of business incentives currently in place is provided in the appendix.

The business support system comprises a broad range of subsidies and incentives for SMEs. Turkey has made significant progress in implementing the Small Business Act of the European Union, a framework plan that caters to improve entrepreneurship and innovation while removing impediments to upscaling and developing, for example through simplifying regulatory policies for SMEs. The support for entrepreneurship, in particular women's entrepreneurship, stands out positively in comparison to other countries (OECD/ETF/EU/EBRD, 2019). The set of incentives provided by TUBITAK, the Scientific and Technological Research Council of Turkey and KOSGEB, the Small and Medium Enterprises Development Organization of Turkey, succeed at enhancing firms' performance, in particular innovation, firm-level productivity and employment (Özçelik and Taymaz, 2008; World Bank, 2019a). Young high-growth firms, however, appear to have worse access to support programmes than older firms (World Bank, 2019a).

While comprehensive, the business support system is overly complex and lacks a regular impact assessment and cost-benefit analysis. In total, 14 different public institutions offered 90 different support programmes in 2018 (OECD/ETF/EU/EBRD, 2019). The generous support system may give rise to unintended side-effects with respect to competition and costs of compliance. It may also risk at incentivising firms to remain in their size category in order to preserve funding from support programmes. The National Development Plan 2019-2023 acknowledged these potential negative side-effects and, in both its sections on "Business and Investment Environment" and "Competitive Production and Efficiency". It emphasised the need to simplify the set of incentives and to back it by a more horizontal effort to enhance the stability and predictability of the support strategy. A step forward would be to enforce the state aid transparency rules established in 2003. These rules were part of the EU convergence programme, which prescribed their systematic and periodical reporting according to EU State Aid rules.

The fiscal cost of business subsidies is large. A review by the Ministry of Treasury and Finance in 2019 found that the revenue forgone through corporate tax incentives amounted to $30 \%$ of the corporate tax due. Authorities should consider more systematic monitoring of all programmes and regular assessments of all interventions against pre-defined objectives. The overarching goal should be to provide support only in cases of market failure and refrain from impeding competition in the business sector otherwise (Cherif and Hasanov, 2019). Based on the results of regular monitoring and cost-benefit assessment, authorities should streamline the business support system to avoid duplication and ensure an efficient use of resources.

Introducing a digital management system that pools information on all available programs combined with firm-level information on applicants and recipients would go a long way in ensuring regular monitoring. It would also provide the necessary base for cost-benefit assessments. Korea, for example, has successfully implemented such a tool to consolidate their SME support system (Randall and Kim, 2014). The so-called "Integrated Management System for Small and Medium Enterprise Aid Programs" enables policymakers to evaluate the cost-effectiveness of programs based on firms' performance. It also provides information on all available aid programmes for business owners in a unified framework, therefore reduces access cost for applicants. The most recent action plan of the Coordination Council for the Improvement of the Investment Environment (YOIKK) includes an initiative to introduce a central management information system. Its main goal is to provide an automated, real-time and reliable data flow of all aid and incentive programs to replace the currently existing "State Aid and Information System (Sais)". A second initiative aims at providing a unified frontend for citizens and applicants and will allow other participating government entities to monitor the status of applications and provide means to check for duplication. In addition, following up on initiatives set out by the Turkish government in the "2021-2023 New Economy Program", the Ministry of Treasury and Finance pursues plans to introduce a comprehensive Incentive and Aid 
Information System, as well as the Ministry of Industry and Technology. The development of such a system goes hand in hand with plans to form a comprehensive legal and regulatory framework for aid and simplifying the current structure while avoiding duplicate applications. These efforts are welcome, but policymakers need to ensure that the responsibility for developing and managing such a system is clearly assigned to one entity and strictly avoid having concurrent systems.

The assessment strategy of business incentives needs to include ex-ante evaluations in form of regulatory impact analysis. Regulatory impact analysis can help to evaluate the cost and benefits of different options, including regulatory and non-regulatory measures, for a specific policy (OECD, 2012). Although Turkey has established the necessary legal framework for conducting mandatory regulatory impact analysis, it is still not used consistently to evaluate economic and budgetary impacts of support programmes (OECD/ETF/EU/EBRD, 2019). On the other hand, a draft presidential decree on the legal and regulatory framework, which defines fundamental rules and principles of aid and incentive programs and ensures more transparency and efficiency but also facilitates ex-ante and ex-post impact assessments, has been proposed to the Presidency.

Ex-ante evaluations of intended policy action should take the views of all stakeholders on board. The Turkish authorities regularly reach out to the private sector regarding new policies. However, a more institutionalised consultation process with frequent transparent private-public consultations can boost regulatory quality and help to underpin rule-making and good governance (OECD/ETF/EU/EBRD, 2019). The Slovak Republic for example, provides access for the general public on all legislative proposals in an unified online system, gathering all relevant information but also allowing the possibility to comment on legislative drafts and their background material. If comments receive enough backing, ministries are required to address the comment in writing, ensuring that the view of relevant stakeholders is properly discussed.

\section{Avoiding size traps in the business tax system}

Statutory corporate tax rates and administrative burdens of paying taxes are broadly in line with the OECD average (Figure 12). However, the corporate income tax base is narrow and tax revenues from corporate income taxes are with $1.9 \%$ of GDP relatively small when compared to other OECD countries. The elevated share of semi-formal and informal business activities can, at least partly, explain the narrow tax base.

\section{Figure 12. Statutory corporate tax rates are moderate}
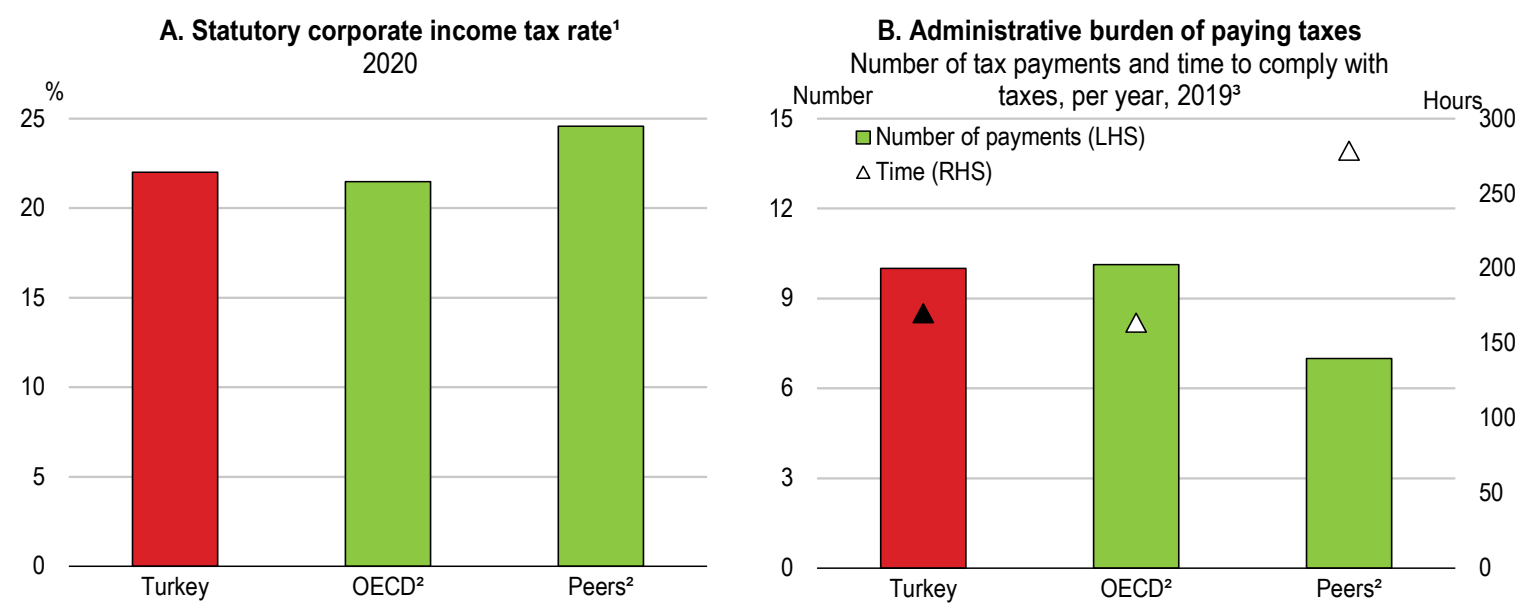

1. Central government corporate income tax rate.

2. Unweighted average. Peer countries refer to the Czech Republic, Chile, Italy, Mexico, Poland, Portugal, and Spain.

3. Data in the 2020 database of which data collection was completed in May 2019.

Source: OECD (2020), OECD Tax database and World Bank (2020), Enterprise survey and Doing Business. 
Table 2. Tax Status of Capital Companies and Sole Proprietorships

\begin{tabular}{|c|c|c|c|c|}
\hline Taxpayers & Tax Type & Tax Rates & $\begin{array}{l}\text { Number of Taxpayers } \\
2018\end{array}$ & $\begin{array}{c}\text { Tax Revenues } \\
\text { 2019, in billion TRL }\end{array}$ \\
\hline Capital Companies & \multirow{3}{*}{ CIT } & \multirow{3}{*}{ Flat Tax Rate (1) } & & 78.8 \\
\hline - Limited Companies & & & 658773 & \\
\hline - Joint Stock Companies & & & 126546 & \\
\hline Sole Proprietorships & PIT & \multirow{3}{*}{ Progressive Tax Rates (4) } & & \\
\hline $\begin{array}{l}\text { - Small businesses (PIT) } \\
\text { (2) }\end{array}$ & Simplified taxation & & 774681 & 0.2 \\
\hline - Others (PIT) (3) & Standard taxation & & $1920586(5)$ & $10.7(6)$ \\
\hline
\end{tabular}

Note: (1) The CIT rate was $20 \%$ in 2017, then it temporarily increased to $22 \%$ for the period $2018-2020$. Distributed dividends are subject to an additional withholding tax of $15 \%$ (PIT). (2) Taxpayers whose annual purchase amount, annual sales or annual workplace rent remain below a certain threshold. For the 2019 calendar year, these thresholds were 120000 TL for annual purchase amount, $180000 \mathrm{TL}$ for annual sales and 9000 TL for annual workplace rent in the boundary of a big city municipality. (3) Book holders on the basis of balance sheets (first class traders) and business accounts (second class traders). (4) The PIT ranges from 15\% to 40\% for five tax brackets. For the 2020 calendar year, the tax rate of $15 \%$ will be applied to annual revenues up to $22000 \mathrm{TL}$ and a tax rate of $40 \%$ will be applied to revenues above $600000 \mathrm{TL}$. (5) The number of PIT taxpayers who receive business profit, agricultural profit and incomes from independent personal services, including traders, farmers, lawyers and doctors.(6) It covers income tax based on declaration and provisional tax revenues.

Besides, $77 \%$ of individual businesses pay taxes via personal income taxation as they are not formally incorporated with tax rates ranging from $15-40 \%$ depending on annual revenues (see Table 2). Roughly, 2 million individual businesses pay taxes via this system, generating a tax revenue of around 11 billion TRY.

Small businesses can use the so-called simplified taxation method if their annual sales, purchases or rents remain under a certain threshold. This entails reduced reporting rules, which in practice may permit to minimise the tax due. Many businesses reportedly confine themselves to this status to avoid standard reporting procedures. Around 750000 small individual businesses report taxes according to this simplified method, generating only a tax revenue of around TRY 0.2 billion. Other OECD countries also employ simplified tax schemes to encourage the development of SMEs. Experience from Hungary and Italy shows, that these tax schemes are effective in decreasing the burden for SMEs, if designed well.

The authorities should carefully monitor and evaluate the effectiveness of simplified tax regimes. The overarching goal should be to allow for a manageable effective tax burden for SMEs of all sizes that does not discourage businesses from upscaling. Regular monitoring and analysis of the impact of simplified taxation on firm growth can help to detect eligibility thresholds that are too high and therefore contribute to avoiding size traps in the business taxation method. The 2021-2023 New Economic Program already includes several policy initiatives which aim at, inter alia, simplifying tax legislations and reviewing tax exemptions. These initiatives are welcome, but policymakers need to ensure that any action is not confined to relatively large and individual businesses.

Business taxation experts in Turkey suggest that average and marginal corporate tax rates in the formal corporate sector are in practice relatively high, contributing to a size trap. At the same time, model simulations using a standard methodology (e.g. Devereux and Griffith, 1999; Devereux and Griffith, 2003) suggest that effective average and marginal tax rates for a simplified hypothetical investment project may be relatively low in international comparison (Hanappi, 2018; Figure 13, Panel A and B). Average corporate income tax rates measure the extensive margin, i.e. the yes or no decision to start a specific project. Marginal effective rates measure the incentive to expand an investment project given that it has already started. 
Figure 13. Effective average and marginal tax rates for a hypothetical investment project
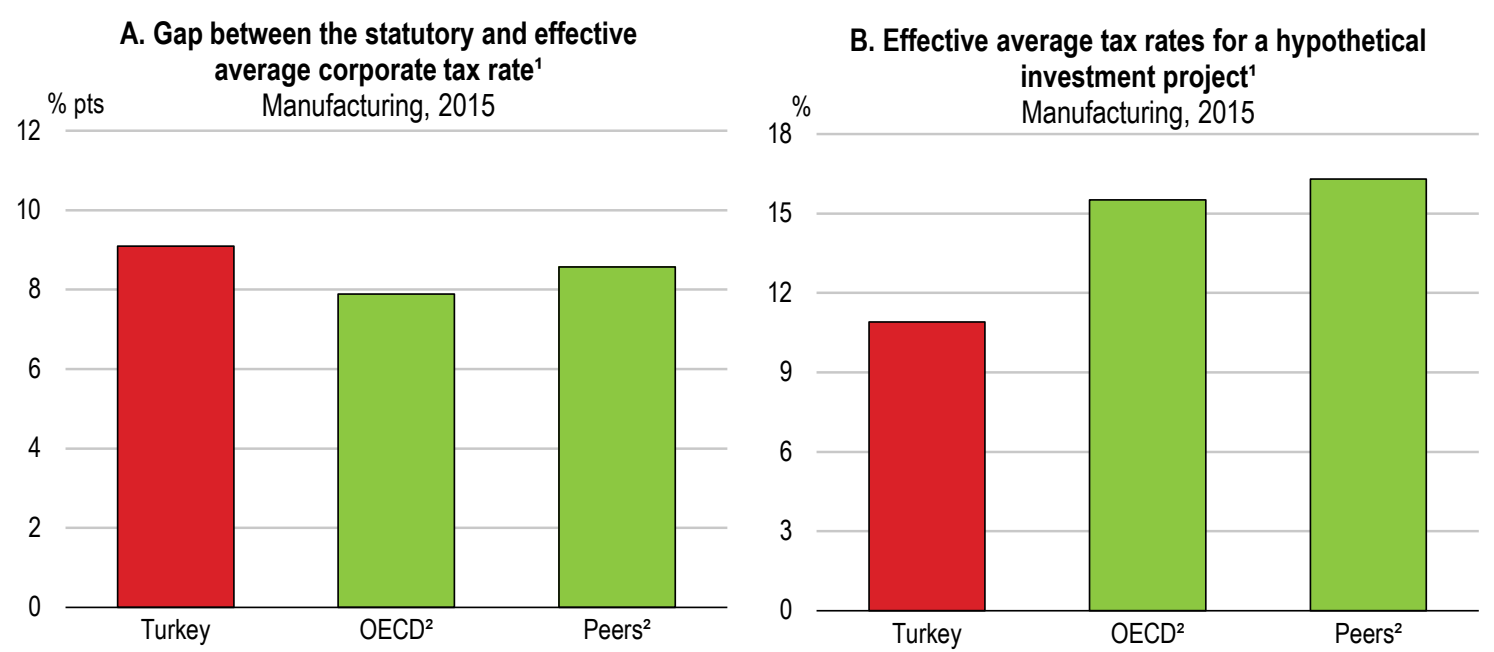

1. Effective average corporate tax rates for debt-financed investment were calculated based on the simulations of the costs of a "hypothetical investment project". See Hanappi (2018) for details on the model assumption (higher inflation and investment scenario 1).

2. Unweighted average. The OECD aggregate includes 32 countries. Peer countries refer to the Chile, Mexico, Poland and Portugal.

Source: OECD (2020), OECD Taxation Statistics (database) and Hanappi, T. (2018), "Corporate Effective Tax Rates: Model Description and Results from 36 OECD and Non-OECD Countries", OECD Taxation Working Papers, No. 38.

Turkey provides one of the most generous tax incentive schemes to R\&D investments across OECD countries. Though the median marginal tax rate across OECD countries for SMEs is $19 \%$, it is around $6 \%$ for Turkey (OECD, 2019b). Furthermore, the tax incentive support for business R\&D has increased significantly since their introduction in 2008. These large incentives have helped to boost R\&D investments and employment in R\&D related activities (OECD, 2016) but also increased complexity. The level of gross domestic spending on R\&D per GDP remains nevertheless low as compared to other OECD countries. While the well-designed annual Tax Expenditure Report provides a complete presentation of tax incentives, including information on aggregate fiscal costs, the impact of tax incentives on subsidisation and competition at the microeconomic level remains opaque. These effects should be monitored. A review of the R\&D tax incentives based on monitoring of potential side-effects would help to prevent incentives and subsidies that overly favour incumbents and better encourage new entrants to upscale. Subsequently, R\&D incentives would contribute to diminishing the large productivity gap across firms through a more efficient "diffusion-oriented" R\&D infrastructure (OECD, 2016).

Improved financial transparency can speed up formalisation and help to reduce tax avoidance. By 2023 and irrespective of firm size, all incorporated firms are required to publish audited financial reports. This will likely decrease possibilities for tax minimisation. However, authorities also need to address tax avoidance by non-incorporated firms given their large share in the business sector. Incentives to make more use of electronic payments can help to address the under-reporting of income. Nevertheless, it is essential that progress towards a more formal and a more level-playing business taxation does not erode Turkey's currently strong entrepreneurial incentives, and entrepreneur's own resources and capacity to invest. 


\section{Addressing the debt overhang}

The leverage of non-financial manufacturing firms has increased (Figure 14, Panel A) since the early 2010s and will be stretched further by the Covid-19 pandemic. However, due to high inflation, leverage ratios of non-financial firms have to be interpreted with some caution, given that total assets tend to be valued at book value whereas current and non-current liabilities, in Turkey usually with low maturity, are valued at market prices. The high level of leverage reflects a build-up of debt since 2010 (OECD, 2018a), exacerbated by the increased value of foreign currency denominated debts following the sharp depreciation of the Turkish Lira following the 2018 currency and debt crisis. Turkey entered 2018 with a positive output gap, a large current account deficit, mostly financed by rather short-term portfolio flows, and elevated corporate debt denominated in foreign currency combined (IMF, 2019). This exposed the Turkish economy to sudden changes in sentiment in international financial markets. Adverse geopolitical developments and increased risk aversion towards emerging markets triggered a pronounced depreciation of the Turkish lira. The central bank increased its policy interest rate by 625 bps in September 2018. As a result, growth plunged in 2018 and unemployment soared.

The rise in leverage has also been attributed to policy action. Besides the large increases of lending to the private sector by public banks (see also KPI), corporates, in particular SMEs, have profited from the expansion of the Credit Guarantee Fund and various support programmes (OECD/ETF/EU/EBRD, 2019). This increase coincided with a restriction on loans in foreign currency and the slowdown in economic growth, which has moderated the accumulation of further debt. Subsequently, the net foreign currency denominated debt position of non-financial firms has edged downwards since 2018.

Debt-to-equity ratios of manufacturing firms are high in international comparison and increased significantly since 2006 (Figure 14, Panel B and D), pointing to relatively low investment of equity capital. These statistics have to be interpreted with some caution. Many informal and semi-formal family-owned enterprises have accumulated unreported equity-type reserves (Yarba and Güner, 2019). Once these "shadow" equity holdings are properly accounted for, actual debt-to-equity ratios may be lower and thus more in line with the OECD average. Further, high inflation in Turkey may contribute to overstating leverage since debt is often valued at market prices whereas equity at book value.

A significant part of the leverage stems from direct liabilities to suppliers or clients through trade credit. Trade credit creates financial linkages and can propagate liquidity or demand shocks (Jacobson and von Schedvin, 2015). Empirical evidence suggests that financially constrained firms, in particular SMEs, tap predominantly trade credit to finance capacity-enhancing investments (Carbo-Valverde, RodriguezFernandez and Udell, 2017). Consistent with the idea that informality is highest and subsequently access to finance is worse across micro-sized firms, nearly $40 \%$ of their total leverage is trade credit. In fighting the financial and economic repercussions of the Covid-19 pandemic, authorities need to monitor carefully the use of trade credit. While policy initiatives like subsidized credits offered by the Credit Guarantee Fund and the 2019 Insurance System for Trade Receivables help, policymakers in Turkey could consider setting up a crisis unit dedicated at monitoring the use of trade credit. Offering credit mediation services can further help to address the risk of propagation of trade credit defaults (OECD, 2020a). 
Figure 14. Leverage of manufacturing firms has increased over time
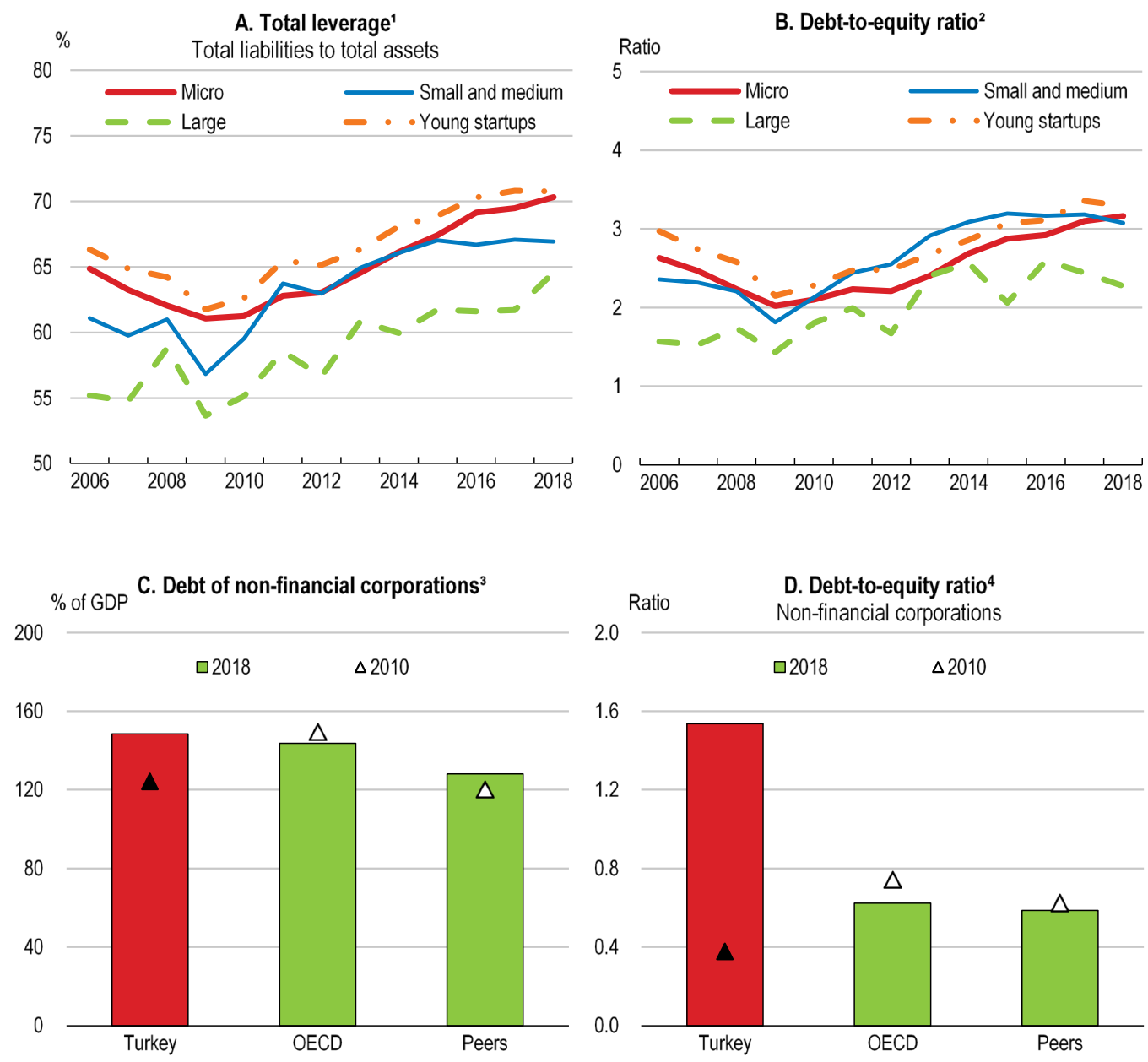

1. The total leverage ratio is calculated as the sum of current and non-current liabilities divided by total assets. Micro-sized firm have less than 10 employees, small- and medium-sized firms between 50 and 250 employees. Firms with more than 250 employees are categorized as large firms. Young startups are firms with a birth year after 2000 and operating in medium-high to high-technology sectors.

2. The debt-to-equity ratio based on EIS data is calculated as the sum of current and non-current liabilities over shareholder funds.

3. In Panel C, debt is defined as all liabilities excluding equity, investment fund shares/units and any liabilities arising from financial derivative contracts (SNA definition). Unweighted average. Peer countries refer to the Czech Republic, Chile, Italy, Mexico, Poland, Portugal, and Spain. 4. In Panel D, the debt-to-equity ratio for international comparisons is calculated as the sum of debt securities (LF3) and loans (LF4) over shares and other equity (LF5) of incorporated non-financial corporations based on non-consolidated data. Peer countries refer to the Czech Republic, Chile, Italy, Mexico, Poland, Portugal, and Spain. OECD and peer country averages are unweighted.

Source: Data in panel A and B are based on the Entrepreneur Information System by the Ministry of Industry and Technology (see also Box 2.2 for more details). Panel $C$ and $D$ are based on the OECD National Account Statistics database.

\section{Reforms of the insolvency system could speed up the economic recovery after the Covid-19 pandemic and improve the allocation of resources}

Turkish authorities have provided ample support for businesses to bridge short-term liquidity shortfalls during the covid-19 crisis, similar to other OECD countries. The combination of elevated leverage ratios before the pandemic, additional debt to bridge liquidity shortfalls and high uncertainty about future sales and profits risks at increasing the amount of non-performing loans and corporate insolvencies. Moreover, a widespread corporate debt overhang, where businesses may lose access to external financing even though their investment projects would still be profitable, can give rise to a painful deleveraging process, 
forcing firms to cut employment and sell valuable assets in fire sales (World Bank, 2020). Public equity injections constitutes a tool to support businesses without increasing already high leverage ratios, although negative side-effects may arise for competition if they are not carefully designed (see also Box 4).

\section{Box 4. Can public equity injections help the corporate sector to weather the COVID-19 shock?}

Public equity injections provide a way to support viable businesses without increasing corporate debt. Equity injections can help firms, which suffer from financial difficulties solely due to COVID-19 shock but are likely to return to profitability afterwards, to raise much-needed cash to finance their working capital while keeping assets free for raising debt in the future. Relative to debt contributions, equity improves leverage ratios and reduces interest coverage ratios, thus benefits corporate refinancing costs. Therefore, equity injections, if well-designed, can help to reduce the risk of a widespread corporate debt overhang.

Authorities would, however, need to ensure that losses for taxpayers are minimised and that the government does not intervene in management. Hybrid instruments like preferred equity appear welladapted. Preferred equity provides a senior claim to dividends and assets in case of liquidation as compared to common equity. Consequently, the owners of common share, i.e. the owners with voting rights, have an incentive to manage the company relatively prudently, given that they only receive a dividend once the dividend payments on preferred shares paid. Since preferred shares entail no voting rights, companies can raise funds without diluting control. Moreover, taxpayer could potentially profit from these investments: If the share of firms in financial distress remains below a certain threshold, public equity injections may even lead to a higher return on investments than compared to debt injections (OECD, 2020b). Temporary forms of preferred equity, e.g. retractable preferred equity, would help to formulate an exit strategy in advance, thus further reducing risks for taxpayers.

Public equity injections come not without disadvantages. Equity injections require agreement on the market value of equity and the required return for investors. Retractable preferred equity further needs agreement on maturity and exit conditions. While valuation and pricing may be much less of a problem for relatively large companies, smaller companies with no shareholders other than the owner are difficult to value. The government could team up with private investors, e.g. private equity and venture capital investors, to ensure a quick and efficient valuation. Valuation at the sector-level may help as well. Crucially, governments need to ensure that competition on markets is not overly distorted and that equity injections do not crowd out other investors.

Turkey introduced a new insolvency and restructuring framework in 2018, explicitly differentiating between bankruptcy and restructuring. The reform included a framework agreement on financial restructurings and more flexible rules regarding arbitration and mediation. The implementation lagged and the insolvency process remains among the most costly in the OECD (Figure 15, Panel A and B). It also has a low recovery rate (Figure 15, Panel $\mathrm{C}$ ). Turkish authorities have expressed their reservations regarding the indicator "Time for creditors to recover their credit" from the World Bank Doing Business Database. The Turkish insolvency system would benefit from insolvency procedures better tailored towards SMEs, for example by offering pre-packaged in-court proceedings tailored towards SMEs (Adalet McGowan and Andrews 2018). Alternatively, decreasing the size and content of mandatory written requirements for restructuring plans for firms below certain thresholds can also contribute to make the insolvency system less costly for SMEs (OECD/ETF/EU/EBRD (2019)). Reforms to the insolvency system would help move resources to more productive firms and sectors, therefore fosters aggregate productivity (Adalet McGowan, Andrews, Millot, 2018), and speeds up the recovery after the pandemic. 
Figure 15. The recovery rate of the insolvency regime is low

Indicators on resolving insolvency, 2020

\section{A. Recovery rate}

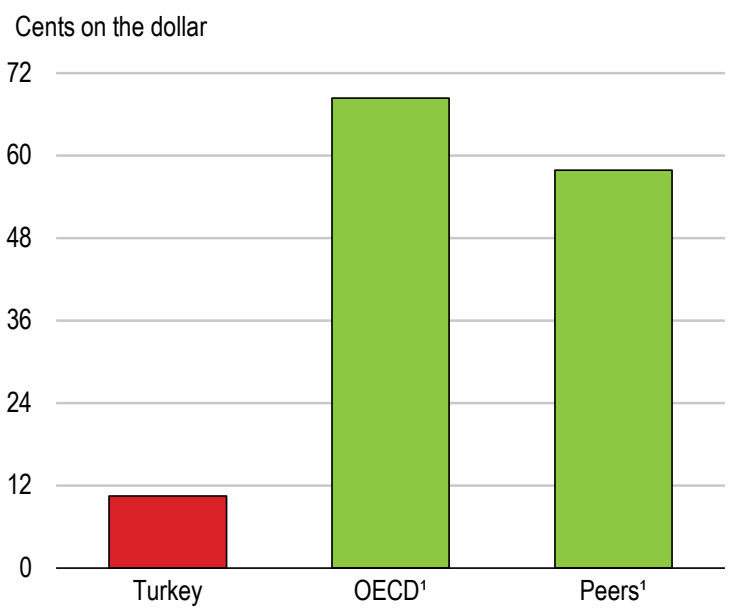

B. Cost of proceedings

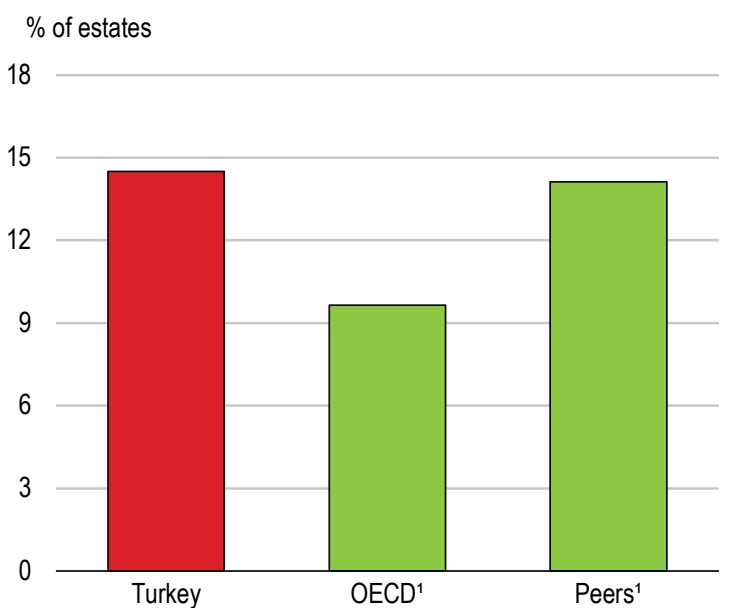

Note: The recovery rate measures the cents on every dollar secured by creditors through judicial reorganisation, liquidation of debt enforcement proceedings. The cost of proceedings is calculated as a percentage of the value of the debtor's estate.

1. Unweighted average. Peer countries refer to the Czech Republic, Chile, Italy, Mexico, Poland, Portugal, and Spain.

Source: World Bank Doing Business (2020).

The relatively costly insolvency regime limits Turkey's capacity to deal with COVID-19 induced corporate insolvencies and increases the likelihood of congested courts. Congested courts tend to increase the likelihood of further refiles for bankruptcy and tend to liquidate smaller firms more often instead of restructuring them (Iverson, 2018). To prepare for a potential wave of corporate insolvencies of otherwise viable but also non-viable businesses, authorities should be prepared to increase the capacity of the insolvency regime, for example by considering informal out-of-court or hybrid restructuring processes (OECD, 2020a; World Bank, 2020). Contrary to fully formal insolvency proceedings, where debtors and creditors negotiate a restructuring or liquidation plan under the supervision of a court or insolvency administrator, out-of-court settlements work without court intervention, while hybrid restructurings constitute a mixture between both. This would supplement the Concordat restructuring adopted in 2018, a framework for formal restructurings under the supervision of a court.

The recent progress on the contractual framework pertaining to financial restructurings will contribute to facilitate the restructuring of financially distressed but otherwise viable businesses, including SMEs. The new Financial Restructuring Framework Agreement under the Turkish Banking Association came with a significant decrease in the threshold qualifying for the financial restructuring framework. Firms with an aggregate principal financial debt of less than TRY 25 million can now profit from a financial restructuring framework geared towards smaller firms. Before the reform, only firms with financial debt above TRY 100 million were eligible. The new framework streamlines the rules for financial restructurings and provides explicit limits on the maximum terms for restructurings. This should help to speed up restructurings, thereby limiting damage on the corporate sector by increasing the amount of preserved organisational and human capital.

Authorities should prepare for a potentially large-scale resolution of non-performing loans (NPL) in banks' balance sheets, given that the COVID-19 pandemic likely increases already elevated firms' leverage ratios. Relying on so-called asset management companies (AMC), which buy non-performing assets from banks 
and other financial institutions with cash or government-guaranteed securities could be an option. Given their expertise in valuing impaired assets, AMCs help to avoid a "market for lemons", i.e. a situation where potential buyers of NPLs on secondary markets offer very low prices for those firms with difficult to value assets, leading banks to forego any sales of NPLs. AMCs contribute to price discovery and provide liquidity on secondary NPL markets (Aiyar et al., 2015). The economy as a whole benefits since the freed up bank capital can be used for credit elsewhere (Cerrutti and Neyens, 2016). Turkey has ample experience with AMCs. As a legacy of the 2000-01 banking crisis, financial institutions have been allowed to sell NPLs on secondary markets to domestic AMCs since 2006. The size of this market increased on average by around $20 \%$ per year (PwC, 2016). Authorities could increase the capacity and liquidity of this market by allowing foreign institutions to acquire Turkish non-performing assets.

\section{Improving the supply of equity capital}

Increased reliance on equity capital would help the over-leveraged business sector to recover from the Covid-19 pandemic and support investment in knowledge-based capital and thus productivity and economic growth (OECD, 2013). Investment into knowledge-based capital requires more equity financing, since intangible investments are more difficult to value and therefore more difficult to use as collateral (Hall and Lerner, 2010). Empirical evidence suggests that innovative activity, as measured by patents and R\&D expenditure, is stronger in countries where equity markets are better developed, in particular in high-tech sectors (Brown, Martinsson, and Petersen, 2007; Hsu, Tian, and Xu, 2014).

Equity markets and other tradeable securities like bonds, commercial papers and securitised trade receivables could play a larger role in financing investment. Market capitalisation of listed companies is at the lower end of OECD countries (Figure 16, Panel A) and well behind peer countries. This is in contrast to the actual number of stock market listings in Turkey, which are comparable to peer countries (Figure 16, Panel C). Stock market liquidity (Figure 16, Panel B) appears solid, thus providing the necessary base for domestic and foreign institutional investors to participate in the Turkish stock market. Blockholders, owners of a large block of shares, control around $61 \%$ of the total market capitalisation in Turkey, roughly similar to peer countries and far above well-developed deep equity markets like the US or UK. On the one hand, blockholders can help to alleviate problems related to the separation of ownership and management and therefore contribute to maximise firm value, for example by improving control over managers and supporting long-term investments. On the other hand, large blockholdings have been associated with lower levels of liquidity. Additionally, blockholdings raise a risk of extracting private benefits at the cost of minority shareholders. The protection of minority shareholders, however, is broadly in line with peer countries (Figure 16, Panel D). Furthermore, the recently enacted reform to the equity market structure of the Borsa Istanbul aims at providing more incentives to increase the share of free floating shares of listed companies. In particular, companies with a free float ratio of less than $5 \%$ now list in the so-called "Pre-Market Trading Platform" where trading follows more stringent rules.

Besides the legal rules pertaining to the protection of minority shareholders, mandatory disclosure requirements are important drivers of the number of stock market listings and the overall size of equity markets (Doidge, Karoyli and Stulz, 2017). Turkish firms are required to disclose a relatively high level of information (Figure 16, Panel E). While this requirement may reduce informational asymmetries, it also leads to high costs. 
Figure 16. Equity markets could play a larger role in financing investment

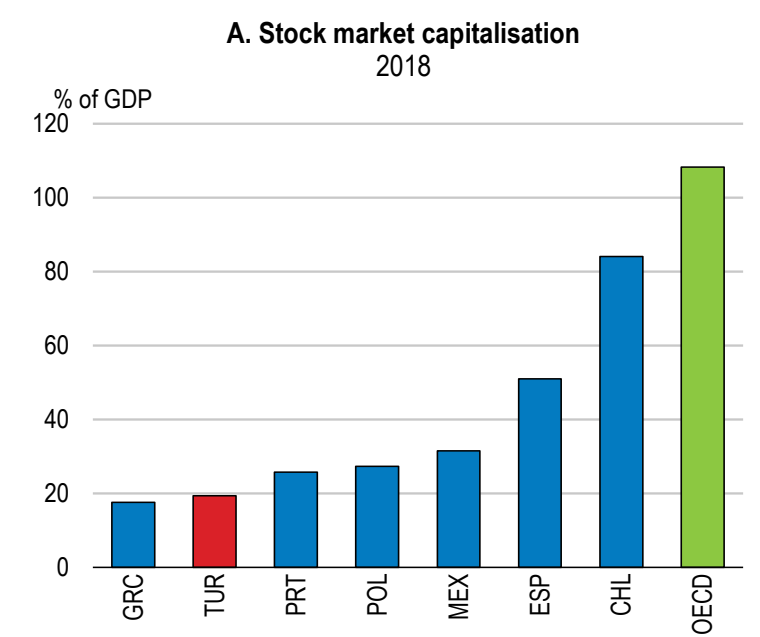

C. Number of listings per GDP (1 million USD) 2018

0.0025

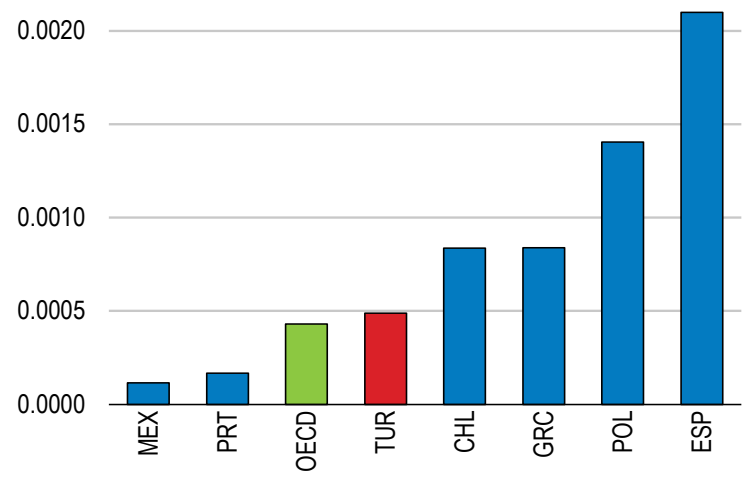

E. Index of business disclosure Scale from 0 to 10 (more disclosure), 2019

10

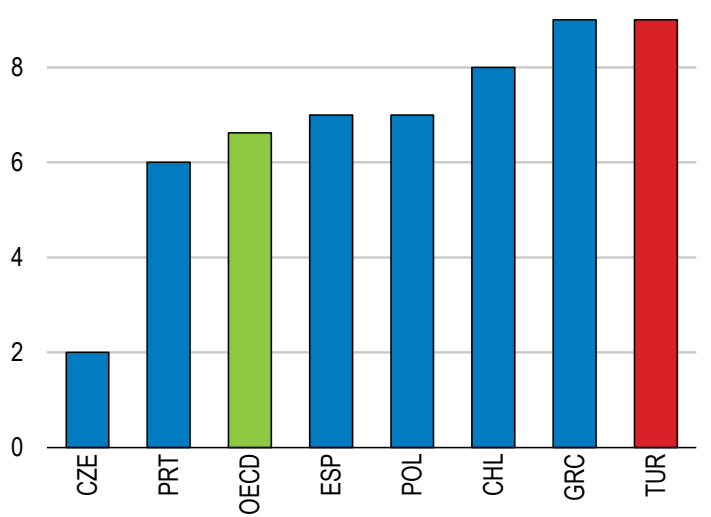

B. Stock market turnover ratio $\%$ of total market capitalization, average between $\% \quad 2011$ and 2018 (or latest year)

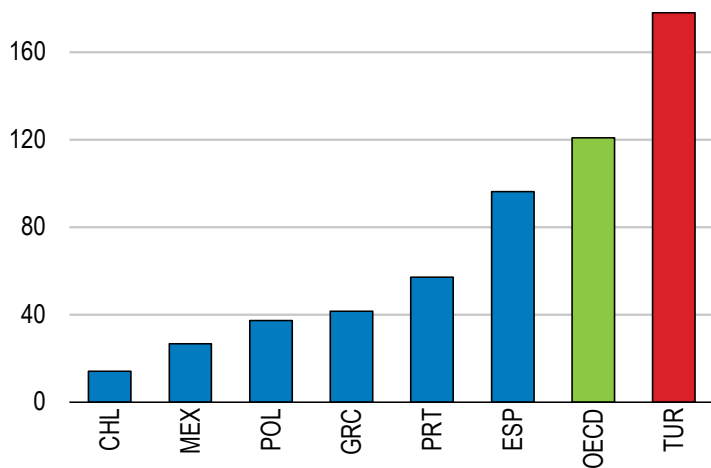

D. Protection of minority shareholder interests Scale from 0 to 7 (best protection), 2017-18

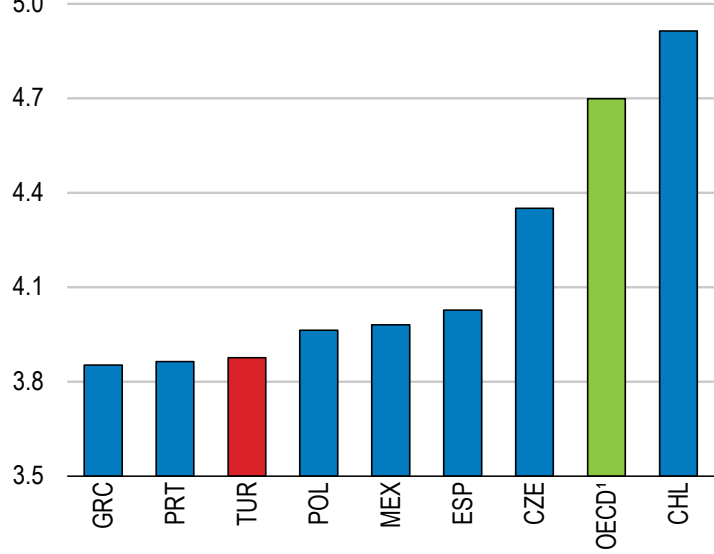

F. Blockholders dominate Turkish stock exchange $\%$ of free-floating, 2018

75

60

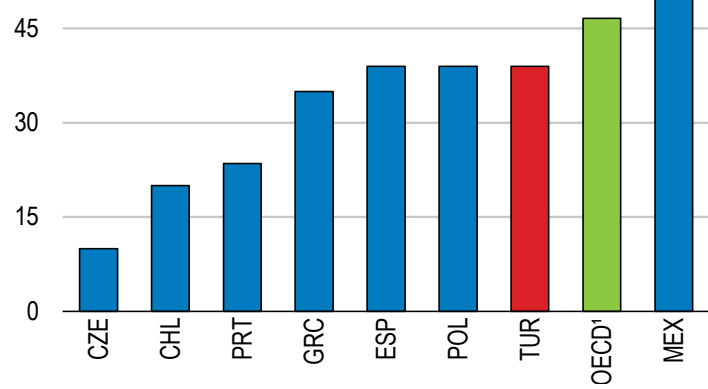

1. Turnover ratio is calculated as the value of domestic shares traded in a year divided by their market capitalisation.

2. Unweighted average.

Source: OECD (2018), OECD Financial Dashboard, World Bank Development Indicators, World Bank Doing Business and Refinitiv. 
The low level of development of equity markets goes hand in hand with elevated costs of capital, in particular equity (Figure 17). The cost of capital measures the rate of return an investor requires to engage in a specific investment project. New firm-level analysis conducted for this paper calculates the cost of capital based on firms' balance sheets and earnings forecasts of financial analysts (see appendix). High costs of equity and debt are negatively associated with investment (Frank and Shen, 2016; Drobetz et al., 2019). Empirical evidence suggests that high quality economic institutions, economic growth, a balanced current account, but also well developed equity markets and low country risk premia are negatively correlated with the cost of equity (see appendix for tabulated regression results). This underlines that any efforts, which lower risk premia, such as a more predictable macroeconomic policy framework and better economic institutions, would help to stimulate the demand for equity capital, thereby reducing the reliance on debt to finance capacity-enhancing investments.

The demand for equity capital can be supported by removing barriers to equity financing in the corporate tax system. Turkey has addressed the debt-bias of the corporate tax system by introducing an allowance for newly issued corporate equity in 2015 . Since this allowance applies to newly issued equity only, the fiscal cost is limited. Such costs would arise if existing equity capital would qualify as well, as it is the case in the Belgian variant (Hebous and Ruf, 2017). The tax shield of the Turkish allowance for corporate equity corresponds to $50 \%$ of every additional unit of equity capital raised, multiplied with a pre-defined return on equity capital equal to the weighted average bank loan interest rate. Higher deductions can be granted to already listed companies under certain conditions. This effectively halves the tax incentive to finance a new investment project by debt. While the allowance amounted to TRY 481 million of foregone corporate taxes in 2019, it is expected to increase to around TRY 300 million in 2021. Empirical evidence suggests that, following the introduction, highly levered firms issued more equity capital and thus could reduce leverage (Ozdamar, Tanyeri and Akdeniz, 2020). Given the need for more equity capital to address overleveraged corporate balance sheets, authorities should consider increasing the allowance from $50 \%$ to $100 \%$ and extending the allowance to retained earnings.

\section{Figure 17. Cost of capital of listed firms is high}

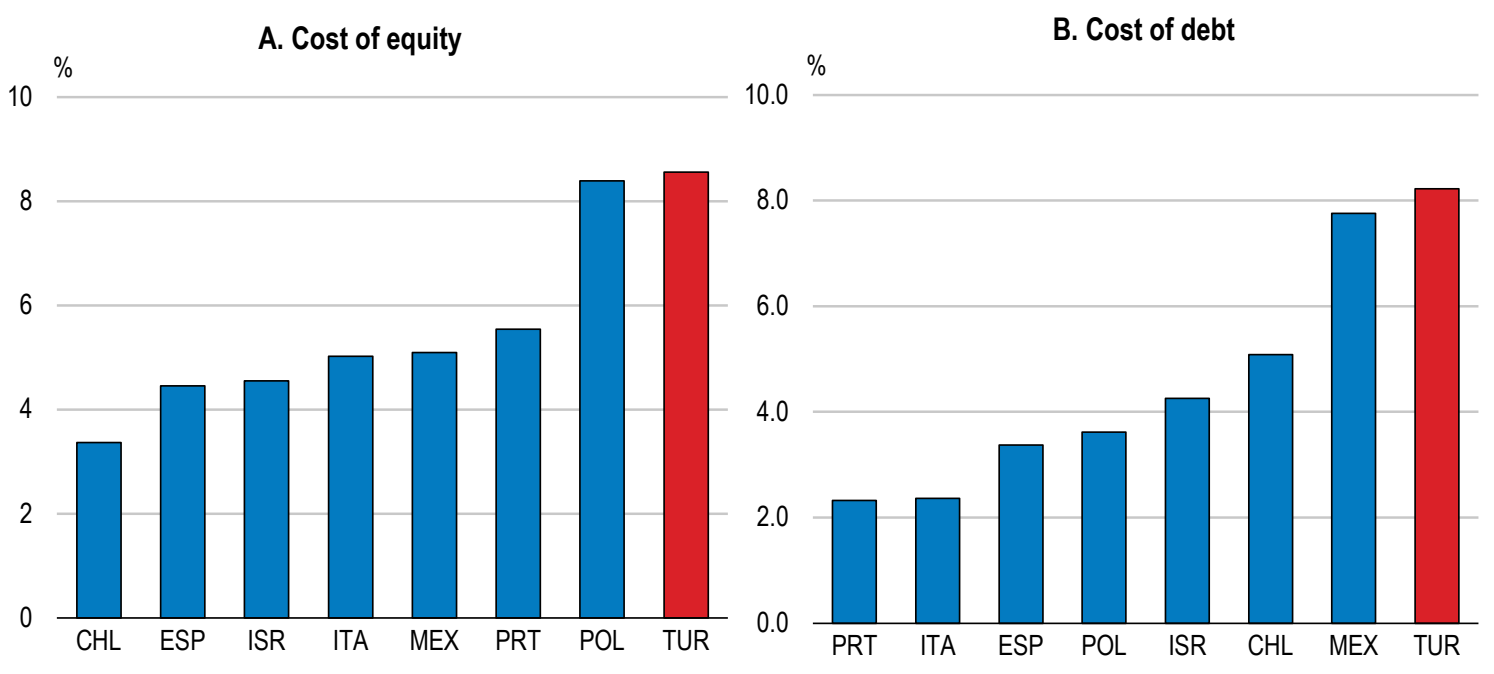

Note: The cost of capital is based on 2018 balance sheet data. Firm sample encompasses all listed non-financial firms in Worldscope. See the appendix for details on the calculation of cost of debt and cost of equity.

Source: OECD calculations based on Refinitv. 


\section{Helping SMEs to raise more equity capital}

Improving the provision of equity capital to SMEs is a major challenge. Stock market segments geared towards SMEs with lower listings costs and less stringent disclosure requirements can incentivize SMEs to list on stock markets. However, such market segments often suffer from low liquidity and low free floating market capitalization putting limits on the participation of institutional investors. The Borsa Istanbul recently reformed its market structure by reducing the number of segments. The segment dedicated towards SMEs, which was small in international comparison (see Table 3), was merged with a segment for bigger companies. This can help to increase the attractiveness of bigger SME listing for example by improving liquidity but also risks at making stock market listings more difficult for smaller SMEs. However, it is questionable whether smaller SMEs should be incentivized to raise equity capital through public listings. Instead, policymakers should consider tax incentives for more specialized investors, like venture capital or private equity. Investments from venture capital or private equity investors could serve as an intermediary step to stock market listings and help smaller SMEs to upscale, to improve corporate disclosure, corporate governance and management practices, thereby building a better base for a successful listing in the future. The outcomes of the past policy efforts to encourage and leverage venture and private equity capital investments with a Treasury-financed "Fund of Funds" should be evaluated.

Tax incentives would benefit a variety of other sources of equity financing, like venture capital, private equity and crowdfunding investments. The UK Enterprise Investment Scheme and Seed Enterprise Investment Scheme for example offers income deductions and reliefs on taxation of capital gains and has been associated with higher investment and employment in smaller firms (European Commission, 2017; Cowling et al. 2008). Turkish authorities have acknowledged the importance of other sources of equity financing to support start-ups and other companies and have launched a number of initiatives, including a change to legal infrastructure to foster other sources of equity investments but also preferential tax treatments for venture capital and private equity investments. According to a recent business sector committee under the supervision of the Union of Chambers and Exchanges (TOBB), the existing government support schemes to these vehicles should be fine-tuned and directed to truly innovative risky investments. Apart from the SME segment at the Borsa Istanbul, a key impediment are, however, the rare exit opportunities beyond IPOs.

Table 3. SME stock market segments in selected emerging markets

\begin{tabular}{|c|c|c|c|}
\hline Country & Name & Number of listings & $\begin{array}{c}\text { Market capitalisation } \\
\text { In Mio. USD }\end{array}$ \\
\hline TUR & BIST ECM & 100 & 208 \\
\hline GRC & ATHEX & 12 & 126 \\
\hline ESP & MAB Expansion & 88 & 11,566 \\
\hline ZAF & AltX & 48 & 1,672 \\
\hline MYS & ACE Market & 115 & 3,559 \\
\hline BRA & Bovespa Mais & 15 & 328 \\
\hline KOR & Kosdaq & 1,267 & 265,176 \\
\hline THA & mai & 150 & 10,140 \\
\hline
\end{tabular}

Note: Market capitalisation end of year 2019 in current USD.

Source: Borsa Istanbul and OECD (2018).

A key requirement to a higher provision of equity capital, in particular for SMEs, are audited financial statements. Audited financial statements provide standardised information on firms' balance sheet and are thus a crucial ingredient in assessing the attractiveness of investments and health of companies. Audited accounts can also help SMEs to obtain bank loans at more favourable rates or longer maturities. Since 2013, the government has lowered size thresholds to increase the numbers of companies subject to 
mandatory audits (see Table 4). If a firm exceeds two of the three thresholds, it qualifies for mandatory audits. Medium-sized firms now qualify. Policymakers should continue to lower the thresholds while ensuring that audit costs do not incentivise firms to stay small and thus forego the benefits of further upscaling.

Table 4. Thresholds for statutory audits in Turkey

\begin{tabular}{l|c|c|c}
\hline \multicolumn{1}{c|}{ Years } & $\begin{array}{c}\text { Net assets } \\
\text { (Million TL) }\end{array}$ & $\begin{array}{c}\text { Net Sales Revenue } \\
\text { (Million TL) }\end{array}$ & Number of Employees \\
\hline 2013 & 150 & 200 & 500 \\
\hline 2014 & 75 & 150 & 250 \\
\hline 2015 & 50 & 100 & 200 \\
\hline 2016 & 40 & 80 & 200 \\
\hline 2018 & 35 & 70 & 175 \\
\hline
\end{tabular}

Source: pwc Istanbul.

Tax incentives for retail investors would contribute to stimulate demand for equity capital in Turkish SMEs. While audited financial statements and good corporate governance provide the necessary ground, a broad base of potential investors interested in SME investment constitute a key requirement for SMEs to tap equity financing through risk capital markets. Tax incentives have proven successful in stimulating supply of equity capital to smaller firms (OECD, 2015). The French PEA-PME framework constitutes an investment scheme, adopted in 2014, that provides tax incentives for investments in listed European SMEs. In the PEA-PME system, retail investors can set up a portfolio of up to EUR 75000 by choosing across a list of listed European SMEs or investment funds which specialise in European SMEs. All dividends and capital gains realised from these investments are exempt from tax (besides generalised social contributions) after a five-year holding period.

A stronger domestic investment management industry would amplify policies that support the development of equity markets. Assets under management in pensions funds and other retirement vehicles were only $3.0 \%$ of GDP, the lowest number across OECD countries besides Greece (OECD, 2019c). Total asset under management were with around $6.3 \%$ of GDP in 2019 relatively low in international comparison. Investment managers play an important role in directing savings to investments (Costanzo, 2011), for example by bundling assets to composites. Retail investors can thus invest in a large number of companies, thereby tapping benefits of diversification, at relatively low costs. Products like funds of funds, i.e. an investment funds that invest in other funds, can help retail investors to access relatively risky and illiquid markets segments like private equity and venture capital at reduced risk. Long-term investments by institutional investors and through already existing instruments have not reached desired levels. It would therefore be helpful to explore options to encourage and incentivize longer-term investments of institutional investors in the real economy. Further, the relatively small share of Turkish firms in popular indexes like the $\mathrm{MSCl}$ world does not allow Turkey to reap the full benefits from passive investment vehicles. A stocktaking of the current state of the investment management industry would help to identify the main constraining factors.

Reliance on Islamic (non-interest bearing) financing vehicles could increase in Turkey and support the recovery of investments after the Covid shock. So far, they have been confined to various forms of leasing, generating around $5 \%$ of total banking sector assets. However, their potential for long-term risk-sharing investments, including from foreign countries in the region, has been acknowledged (link). The government has recently stated that the "Istanbul Financial Centre" shall also be a global hub for Islamic Finance (link). 
Improved financial literacy increases investors' participation in stock markets and helps entrepreneurs to better understand the advantages and disadvantages of equity financing (v. Rooij, Lusardi and Alessie, 2011). Importantly, measures to ameliorate financial literacy should be geared to both investors and entrepreneurs. A better understanding of implications and consequences of decisions pertaining to the management of the capital structure can help to increase the appetite for equity capital by addressing common misconceptions (Boschman and Pissareva, 2017), for example that raising equity capital leads to a loss of control. Results from the OECD/INFE cross-country survey on financial literacy suggest that Turks have above average financial literacy. However, aggregate indexes of financial literacy may mask knowledge gaps in areas directly related to the stock market, for example the understanding of volatility, correlation and diversification. In Turkey, there are various initiatives to improve financial literacy, financial education and consumer protection. Regarding entrepreneurs, KOSGEB promotes their financial literacy through an online platform, called the SME campus (OECD, 2019a). Apart from this initiative, financial education is not taught on a mandatory basis in Turkish schools as a separate subject, though aspects related to financial knowledge are included in various compulsory courses like life studies, mathematics, social studies and science courses.

\section{Tapping the benefits of increased adoption of digital technologies}

The COVID-19 pandemic has shown the key role that well-developed and fast broadband networks can play, but also underlined the importance of a good IT infrastructure and the use of digital technologies across businesses and households. The authorities should build on this increased attention and readiness to use digital technologies in work and daily life to further advance the digitalisation of the economy. The benefits would be large. A more widespread use of comprehensive ICT tools and activities, such as enterprise resource planning software (ERP), customer relationship management software (CRM) or cloud-computing, is positively associated with productivity growth (Gal et al., 2019). Digitalisation can also help small- and medium-sized firms to grow and upscale without having the critical mass for tapping efficiency gains from economies of scale, thereby significantly reducing size disadvantages of SMEs (OECD, 2019a). In this regard, the Ministry of Industry and Technology has been developing various strategy documents to boost digitalisation in the Turkish industry, especially across SMEs. The "Digitalisation Strategy", a part of the 2023 Industry and Technology Strategy, will include solutions and support mechanisms for enterprises of all sizes. In particular, it plans to measure the readiness of companies for digitalisation and in a second step, to support businesses through existing but also new solutions with the ultimate goal to increase the capacity to use ICT tools and activities.

Digitalisation could ease small- and medium-sized firms' access to domestic and international markets by creating new opportunities for the participation in export markets and global value chains (WTO, 2019). In addition, ICT tools and activities allow SMEs to tap strategic resources, like skilled workers, more easily and less costly (OECD, 2017). Cloud computing, as well as robotics and big data, appear particularly promising for SMEs. Cloud computing allows the use of digital technologies from corporate email solutions to ERP and CRM software packages on a pay-for-use basis without having to invest in the underlying IT infrastructure and IT staff (OECD, 2019a). 


\section{Figure 18. Turkish firms lag behind in the adoption of advanced ICT tools and activities}

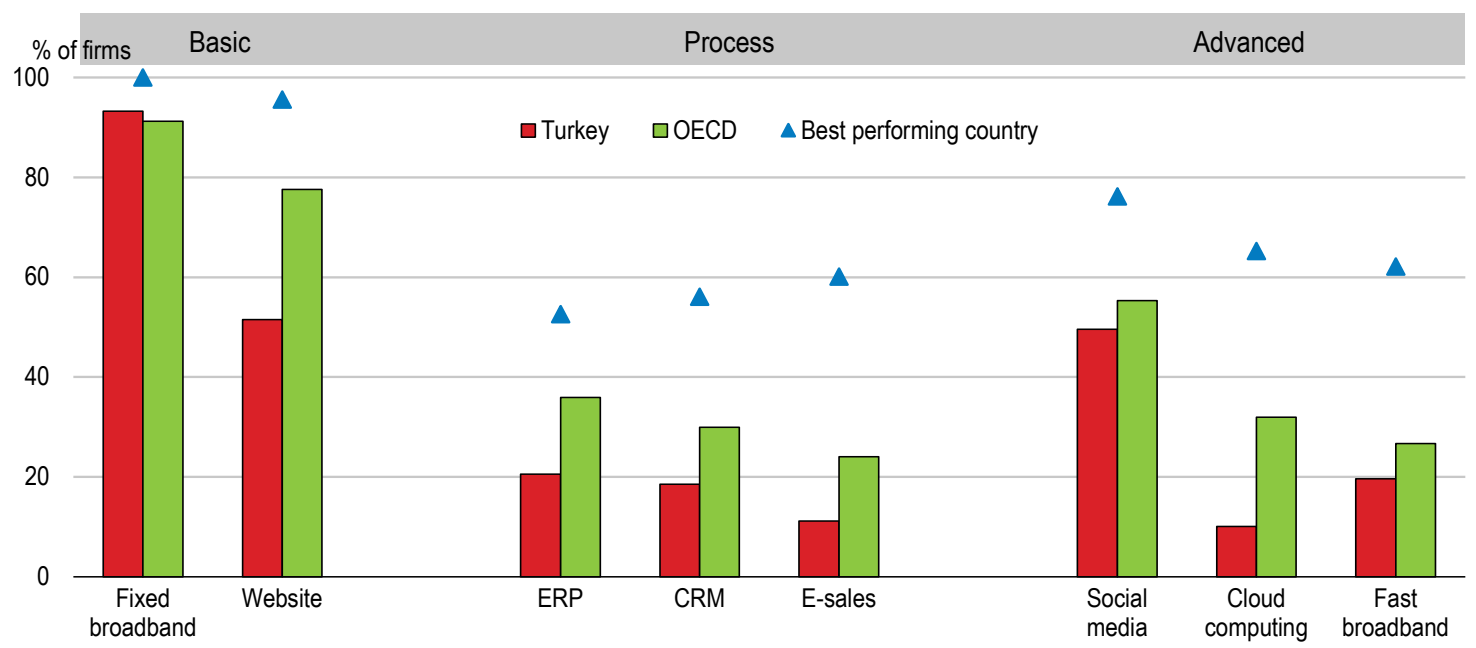

Note: Based on firms with 10 employees and more. Unweighted average for the OECD aggregate. ERP stands for enterprise resource planning, CRM for customer relationship management; high-speed broadband are subscriptions with $100+$ Mbps.

Source: OECD ICT Access and Usage by Businesses database.

The adoption of advanced ICT tools and activities lags behind other OECD countries (Figure 18). In Turkey, only $68 \%$ of large enterprises employ ERP software, lower than the OECD average of $78 \%$. For small- and medium-sized firms, adoption rates, at $16 \%$ and $37 \%$ respectively, are among the lowest across OECD countries. The adoption rates of CRM of small firms are low compared to the OECD average, though several OECD countries have similarly low rates. Turkish medium and large enterprises lag behind in the use of CRM software compared to other OECD countries. The use of cloud computing across Turkish firms shows a similar pattern. Turkey, however, made significant progress regarding basic ICT tools and activities. Most businesses have, however, access to broadband, offer a website or make e-purchases (OECD, 2018a).

\section{Improving digital skills}

Digital skills and access to fast broadband are two key bottlenecks that impede a more widespread adoption of ICT tools and activities (Figure 19). According to a survey conducted by the European Commission, only $31 \%$ of Turks between the age of 16 and 74 have basic or above basic skills (Figure 19, Panel A). This contrasts with survey results from the Turkish Statistical Institute, which show that the majority of the population uses the internet (approx. 75\%) and computers (approx. 60\%) regularly. The survey of the European Commission measures digital skills through a variety of basic tasks, not only related to the use of the internet and computers but also pertaining to information retrieval, communication, problem solving and software skills. However, the digital skills of Turks improved significantly compared to 2015. The aggregate statistics on digital skills may mask important differences across age groups. Digital natives are likely to be younger and have significantly better skills than older people. However, younger Turks have less advanced IT skills and related cognitive skills to evaluate problems and solutions than in other OECD countries (OECD, 2016). The low level of average problem-solving skills in technology-rich environments coincides with lower proficiency in literacy and numeracy of adults and low upper secondary attainment (OECD, 2018a).

Changes to school curricula, hackathons, coding camps and competitions may stimulate children and students to improve basic and advanced ICT skills. Guided by Turkey's Education Vision 2023, Turkey has succeeded in streamlining entrepreneurship learning in the curricula at all levels of education, launched 
several entrepreneurship project and clubs in schools and promoted the benefits of entrepreneurship widely with the help of the media (OECD/ETF/EU/EBRD, 2019). Turkey has also a good performance at international competitions related to problem-solving skills, e.g. at the International Math Olympics. The training centre of the ICT regulatory authority (BTK) provides training opportunities for children and young students and hosts a comprehensive online database of training material free of charge. Nevertheless, by leveraging on this existing infrastructure and the organisational capital build for entrepreneurship learning, policymakers should mainstream the uptake of digital skills in school curricula to ensure a wide dissemination. Importantly, the outreach and design of competitions needs to appeal to both sexes to avoid any gender bias. Turkish policymakers are well aware of the need to boost digital skills. Various policy educational programmes on improving digital skills, including cybersecurity, are already developed and provided in schools, universities and through online platforms. Moreover, the National Cyber Security Strategy and Action Plan includes strategic goals to increase basic and advanced digital skills. In particular, the National Cyber Security Strategy and Action Plan 2020-2023 has short term and long term strategic targets that intend to enrich school curricula with content related to cyber security. Increasing the number of graduate and post-graduate in programmes related to cyber security constitutes a further goal. In this respect, various action items have already been defined to advance the development of educational programmes and academic curricula related to cybersecurity.

\section{Access to high-speed broadband constitutes a bottleneck}

The number of fixed broadband subscriptions at higher speed tiers across Turkish households and firms is relatively low (Figure 19, Panel B). However, the average household size in Turkey is with around 3.35 people, relatively higher than in other OECD countries, implying that irrespective of internet speed, the number of people having internet access is higher than the number of internet subscriptions. While the share of firms with access to broadband is with around $95 \%$ very high, only around $37 \%$ have access to fast broadband. Fast broadband access provides the base for a wide range of ICT tools and activities, in particular cloud computing and data-intensive applications (Andrews, Nicoletti and Timiliotis, 2018). The last broadband market analysis conducted in 2019 includes new requirements on fibre infrastructure and fibre services which aim at enhancing competition in telecommunications markets and encourage operators to also provide broadband services at higher speed tiers.

Besides benefitting productivity, improvements in digitalisation promote the formalisation of the economy. Using digital platforms, governments can reduce the cost of compliance with labour and product regulation and tax rules (World Bank, 2019c), even without regulatory or tax changes. Thus, e-government constitutes a cost-effective way to foster formality, as revealed in Costa Rica. In 2009, Costa Rica set up a web service where corporations could register as taxpayers and disclose their company accounts (World Bank, 2009), effectively reducing the time to start a new business by 17 days. In the aftermath, the share of employment in the informal sector dropped by 4 percentage points (World Bank, 2019c). 
Figure 19. Digital skills and low numbers of high speed broadband subscriptions impede the adoption of advanced digital technologies

A. Digital skills are low

$\%$ of individuals aged 16-74 Percentage of individuals who have basic or above basic overall digital skills

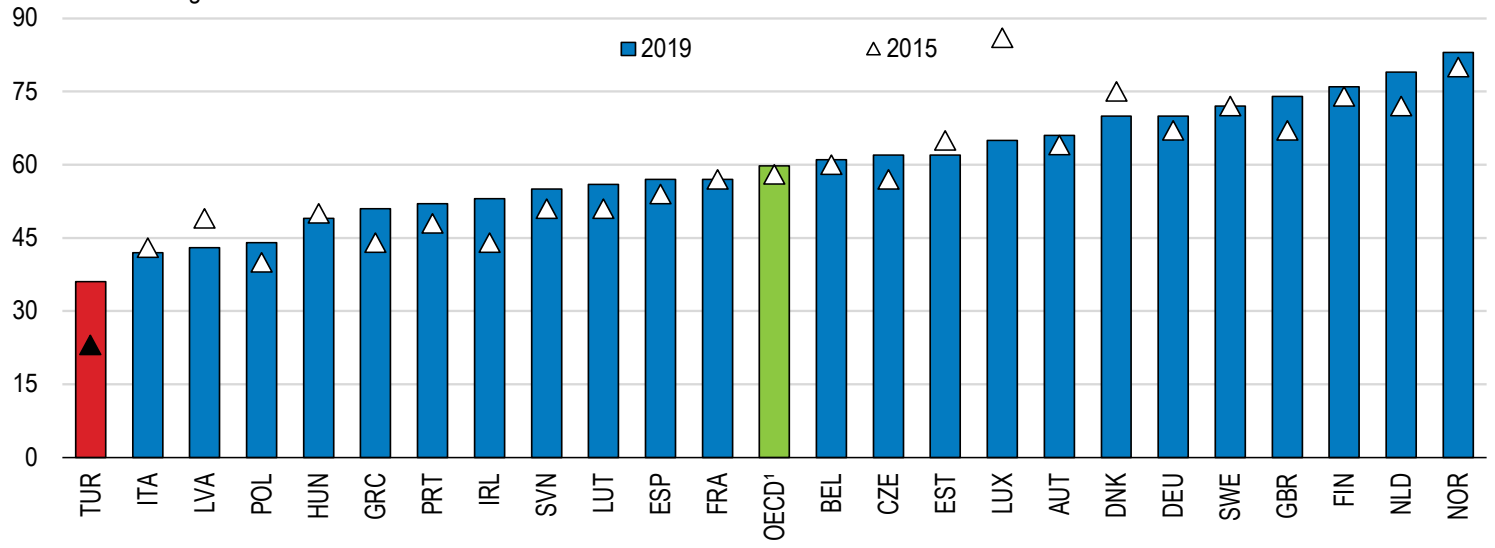

B. The number of broadband subscriptions is low ${ }^{2}$

Per 100 inhabitants Fixed broadband subscriptions per 100 inhabitants, per speed tiers, December 2019

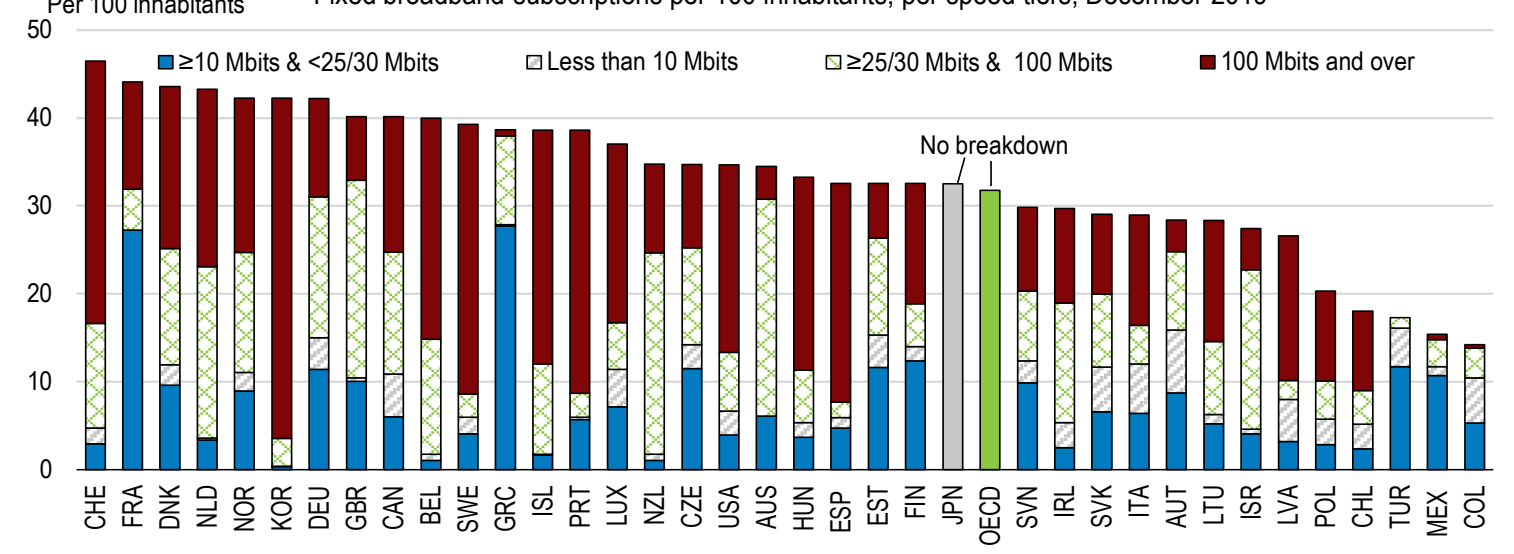

1. The indicator is based on the EU survey on the ICT usage in households and by individuals. Specifically, the digital skills indicator measures basic and above basic skills related to internet or software use performed by individuals aged 16-74 in four specific areas (information, communication, problem solving, software skills) The OECD aggregate corresponds to the unweighted average of the shown European countries' data.

2. See OECD, Broadband Portal for detailed methodological information in data collection.

Source: Eurostat (2020), Individuals who have basic or above basic overall digital skills by sex (online data code: TEPSR_SP410) and OECD, Broadband Portal, www.oecd.org/sti/broadband/oecdbroadbandportal.htm. 


\section{Recommendations}

\section{Removing regulatory barriers to firms' growth will promote productivity}

- Make progress, in collaboration with EU partners, with the extension of the Customs Union agreement to agriculture, services and public procurement. Roll-back the temporary trade protection measures as planned.

- Undertake a critical review of the impact on competition, prices and mark-ups of restrictions in sophisticated professional and network services.

\section{Streamlining business incentives can sharpen their effectiveness}

- Introduce a digital management system, similar to the monitoring system for SME aid programs in Korea, to better supervise and monitor business incentives.

- Report all programmes according to state aid transparency rules and systematically assess all programmes using ex-ante and ex-post evaluations.

- Adopt a more institutionalised approach to business consultation by introducing a formal requirement to conduct transparent and mandatory public-private-consultations.

Avoiding size traps in the business taxation system

- Consider conducting an in-depth review of incentives to R\&D to further boost R\&D investment of businesses while ensuring a level-playing field for competition.

- Continue making corporate taxation of different firms sizes converge in order to minimise traps related to size-thresholds.

- Use regular monitoring and evaluations to simplify and streamline tax incentives for tangible and intangible investments.

- Report all tax incentives according to State Aid Transparency rules.

\section{Addressing overleveraged balance sheets}

- Encourage new equity injections and the re-capitalisation of non-financial firms in order to restore their investment capacity after the COVID-19 shock. Remove any remaining obstacles to their upscaling.

- Implement the recently introduced arbitration, mediation and framework agreement measures for financial restructurings. Be prepared to phase in additional measures to help courts to deal with insolvencies in case of need.

- Allow foreign investors to participate in secondary markets for non-performing loans.

- Introduce insolvency procedures geared towards SMEs, for example by offering pre-packaged in-court proceedings or decreasing the size and content of mandatory written requirements for restructuring plans.

- Set up a unit dedicated at monitoring the use of inter-company trade credit and preventing a propagation of financial distress across firms.

- Continue to decrease the size threshold for mandatory audited financial statements while ensuring that audit costs for smaller firms do not provide disincentives to upscaling.

- Introduce financial education as a mandatory subject in schools to boost financial literacy of investors and entrepreneurs, while ensuring that financial education is gender-inclusive.

Tapping the large dividends of increased adoption of digital technologies

- Develop a holistic strategy for digital skills and better mainstream digital skills in school curricula.

- Consider an in-depth review of competition on broadband networks to address the low uptake of broadband subscriptions, in particular at higher speed tiers. 


\section{Bibliography}

Acemoğlu, D. and M. Üçer (2019),"High-Quality Versus Low-Quality Growth in Turkey: Causes and Consequences" CEPR Working Paper, No. DP14070.

Acemoglu D. and M. Üçer (2020), "The Ups and Downs of Turkish Growth", unpublished mimeo.

Adalet McGowan, M. and D. Andrews (2018),"Design of Insolvency Regimes Across Countries", OECD Economics Department Working Papers, No. 1504.Adalet McGowan, M., D. Andrews and V. Millot (2017),"Insolvency regimes, zombie firms and capital reallocation", OECD Economics Department Working Papers, No. 1399.

Adalet McGown, M., D. Andrews and V. Millot (2018),"The walking dead? Zombie firms and productivity performance in OECD countries", Economic Policy, October 2018.

Adrian, T. et al. (2020), A Quantitative Model for the Integrated Policy Framework, Working Paper, No. 20/122, IMF.

Akçigit, U., Akgündüz, Y. E., Cılasun, S.M., Özcan-Tok, E., \& Yılmaz, F. (2020),"Facts on Business Dynamism in Turkey", European Economic Review, Vol. 158.

Akcigit, U. and Y. E. Akgündüz (2020), "Turkiye'de COVID-19 Odakli Talep Soklarinin Cografi ve Sektorel Yayilimi", Working Paper, Chicago University.

Akgündüz, Y.E., Aldan, A., Bagır, Y.K. and H. Torun (2019), Job mobility in Turkey, Central Bank Review, Vol. 19/3, pp. 83-91.

Alper K., H. Kara and M. Yörükoğlu (2013), "Alternative tools to manage capital flow volatility", B.I.S. Paper.

Andreasen, E., S. Bauducco and E. Dardati (2019), Capital Controls and Firm Performance, Working Paper Series, No. 331/2019, ILADES-UAH,

Andrews, D., G. Nicoletti, and. C. Timiliotis (2018),"Digital Technology Diffusion: A Matter of capabilities, incentives, or both?", OECD Economics Department Working Papers, No. 1476.

Aiyar, S., W. Bergthaler, J.M. Garrido, A. Ilyina, A. Jobst, K. Kang, D. Kovtun, Y. Liu, D. Monaghan, and M. Moretti (2015),"A Strategy for Resolving Europe's Problem Loans", IMF Staff Discussion Note, SDN/15/19.

Ari, A., S. Chen and L. Ratnovski (2020), "COVID-19 and non-performing loans: lessons from past crises", Research Bulletin, No.71, European Central Bank.

Atabek Demirhan A. (2020), "Türk Imalat Sanayi Firma Performansi Analizi: Diş Tcaret Faaliyetleri Açisindan Bir Inceleme", in "Uluslararası Ticarette Güncel Konular", İstanbul Kültür Üniversitesi yayınları, 2020.

Atiyas, İ., O. Bakış and Y. K. Orhan (2017),"Firm Dynamics and Job Creation in Turkey - Some Preliminary Results", Working Paper, Sabanci University, 2017-1.

Bankovic, A. (2019), Potential for the Future: Renewable Energy Investments in Turkey, EEL Events Blog.

BBVA Research (2020), Turkey GDP is slumped but beat market expectations.

Benigno et al. (2020), Credible emerging market central banks could embrace quantitative easing to fight COVID-19, CEPR.

Bircan, C. and O. Saka (2019), 'Lending cycles and real outcomes: costs of political misalignment", Working Paper, No. 225, EBRD.

Bloom, N. and J. van Reenen (2010),"Measuring and Explaining Management Practices across Firms and Countries", Journal of Economic Perspectives, Vol. 24 (1).

Boeri, T. et al. (2019), Wage Equalization and Regional Misallocation: Evidence from Italian and German Provinces, Discussion Paper Series, No. 12279, IZA Institute of Labor Economics. 
Boschman, K., and L. Pissareva (2017),"Fostering Markets for SME Finance", OECD SME and Entrepreneurship Papers, No. 6.

Brown, J.R., S.M. Fazzari, and B.C. Petersen (2009),"Financing Innovation and Growth: Cash Flow, External Equity and the 1990s R\&D Boom", Journal of Finance, Vol. 89 (3).

BRSA (2020), Press Release (About Derivative Transactions), Banking Regulation And Supervision Agency

Cakmakli C. and S. Demiralp (2020), "A Dynamic Evaluation of Central Bank Credibility", Selva Demiralp: Department of Economics, Koc University Koç University-TUSIAD Economic Research Forum Working Papers.

CBRT (2019), Monetary and Exchange Rate Policy for 2020, Central Bank of the Republic of Turkey.

CBRT (2019), Financial Stability Report November 2019, Central Bank of the Republic of Turkey,

Çolak et al. (2019), "Monitoring and Forecasting Cyclical Dynamics in Bank Credits: Evidence from Turkish Banking Sector", Working Paper, No. 19/29, CBRT.

Carbo-Valverde, S., F. Rodriguez-Fernandez and G.F. Udell (2016),"Trade Credit, the Financial Crisis, and SME access to Finance", Journal of Money, Credit and Banking, Vol. 48 (1).

Cerrutti, C., and R. Neyens (2016),"Public Asset Management Companies: A Toolkit", World bank Studies, Washington D.C.: World Bank.

Çetinkaya, Ö. (2014). "Kamu Ihale Kanunu ve Yolsuzluk Riskleri”. Bursa: Ekin Yayınevi.

Çetinkaya, Ö., E. Eroğlu (2020),"An Assessment of the Public Procurement System in Turkey", Public Financial Management Reforms in Turkey: Progress and Challenges, Vol. 1.

Cherif, R. and F. Hasanov (2019),"The Return That Shall Not Be Named: Principles of Industrial Policy", IMF Working Paper, WP/19/74.

Constanzo, G.L. (2011),"The Contribution of the Asset Management Industry to Long-term Growth", OECD Journal: Financial Market Trends, Issue 1.

Cowling, M., P. Bates, N. Jagger, and G. Murray (2008),"Study of the impact of Enterprise Investment Scheme (EIS) and Venture Capital Trusts (VCT) on company performance", HM Revenue \& Customs Research Report 44.

Council of Europe / GRECO (2018), Fourth Evaluation Round: Corruption prevention in respect of members of parliament, judges and prosecutors, Compliance Report Turkey.

Cournède, B., J. Fournier and P. Hoeller (2018), "Public finance structure and inclusive growth", Economic Policy Paper, No. 25, OECD Publishing, Paris.

Criscuolo, C., P. N. Gal, and C. Menon (2014),"The Dynamics of Employment Growth", OECD Science, Technology and Industry Policy Papers, No. 14.

Decker, R.A., J. Haltiwanger, R. S. Jarmin and J. Miranda (2016), "Declining Business Dynamism: What We Know and the Way Forward", The American Economic Review, Vol. 106 (5).

Decker, R.A., J.C. Haltiwanger, R.S. Jarmin and J. Miranda (2018), "Changing Business Dynamism and Productivity: Shocks vs. Responsiveness", NBER Working Paper Series, No. 24236.

Del Carpio, X., and T. Taskin (2019),"Quality of Management of Firms in Turkey", Jobs Working Paper No. 27, World Bank.

Demiralp S. (2020), "Turkey's Three Months Covid-19 Performance”, Yetkin Report

Devereux, M.P. and R. Grifftith (1999),"The Taxation of Discrete Investment Choices", Institute for Fiscal Studies Working Paper Series, No. W98/16.

Devereux, M.P. and R. Grifftith (2003),"Evaluating Tax Policy for Location Decisions", International Tax and Public Finance, Vol. 10.

Doidge, C., G.A. Karolyi, and R.M. Stulz (2017),"The U.S. listing gap", Journal of Financial Economics, 
Vol. $123(3)$.

Drobetz, W., S. El Ghoul, O. Guedhami, and M. Jenzen (2018),"Policy uncertainty, investment, and the cost of capital", Journal of Financial Stability, Vol. 39.

Egilmez, M. (2020), Merkez Bankası Rezervlerinin Yeterliliği,

Estevão, M. and G. Everaert (2016), Enhancing Monetary Policy Flexibility Through 'De-dollarization', IMF Blog.

Ergun, D., O. Gouveia and A. Ortiz (2017), International experiences of De-dollarization: What could be done in the Turkish case?, BBVA Research.

Erdogdu, E. (2013), "'Motor fuel prices in Turkey", MPRA Paper, No. 55521.

European Commission (2017), "Effectiveness of tax incentives for venture capital and business angels to foster the investment of SMEs and start-ups", Final Report TAXUD/2015/DE/330.

Egitimsen (2020), Salgin Gunlerinde Uzaktan Egitim Calistayi Sonuc Raporu, 4 Eylul 2020.

European Commission (2019), Key findings of the 2019 Report on Turkey.

Faccio, M. (2006),"Politically Connected Firms", The American Economic Review, Vol. 96 (1).

Financial Action Task Force (2019), Anti-money laundering and counter-terrorist financing measures in Turkey, Mutual Evaluation Report: Turkey.

Frank, M. Z. and T. Shen (2016),"Investment and the weighted average cost of capital", Journal of Financial Economics, Vol. 199.

Gal, P., G. Nicoletti, T. Renault, S. Sorbe, and C. Timiliotis (2019), "Digitalisation and Productivity: In Search of the Holy Grail - Firm-level empirical evidence from European Countries", OECD Economics Department Working Papers, No. 1533.

Gamberoni, E., C. Giordano, P. Lopez-Garcia (2016), "Capital and labour (mis)allocation in the euro area : some stylized facts and determinants", ECB Working Paper Series, No. 1981.

Gürakar, E. Ç. (2016), Politics of Favoritism in Public Procurement in Turkey: Reconfigurations of Dependency Networks in the AKP Era, Palgrave Macmillan.

Gaspar, V., M. Muhleisen and R. Weeks-Brown (2020), Corruption and COVID-19, IMF Blog.

Gürsel S. and G. Uysal (2020), « Korona Gunlerinde Turkiye Isgucu Piyasasi », in O.F.Colak ed. (2020) « Korona Krizinde Turk Ekonomisi », Elif Yayinlari, forthcoming.

Gönenç, R., S. Sahinoz and O. Tuncel (2010), "Turkey's Improving Integration with the Global Capital Market: Impacts on Risk Premia and Capital Costs", OECD Economics Department Working Papers, No. 812.

Gönenç, R. (2017), The middle income plateau: Trap or springboard?, OECD Economics Department Working Papers, No. 1446, OECD Publishing, Paris.

Hall, B.H. and J. Lerner (2010),"Chapter 14 - The Financing of R\&D and Innovation", in Handbook of the Economics of Innovation, Vol. 1.

Hanappi, T. (2018),"Corporate Effective Tax Rates", OECD Taxation Working Papers, No. 38.

Hebous, S. and M. Ruf (2017),"Evaluating the effects of ACE systems on multinational debt financing and investment", Journal of Public Economics, Vol. 156.

Hsu, P.-H., X. Tian, and Y. Xu (2014),"Financial Development and innovation: Cross-Country evidence" Journal of Financial Economics, Vol. 112 (1).

Haberler.com (2020), İşletmeler çıkış yolunu yeni ürün ve hizmette arıyor.

Huizinga, H. and L. Laeven (2019), "The Procyclicality of Banking: Evidence from the Euro Area",

Discussion Paper Series, No. 13605, CEPR.

IMF (2019), IMF Executive Board Concludes 2019 Article IV Consultation with Turkey.

IMF (2020), 2020 External Sector Report: Global Imbalances and the COVID-19 Crisis. 
Iverson, B. (2018),"Get in Line: Chapter 11 Restructuring in Crowded Bankruptcy Courts", Management Science, Vol. 64 (11).

Jacobson, T. and E. von Schedvin (2015),"Trade Credit and the Propagation of Corporate Failure: An Empirical Analysis", Econometrica, Vol. 83 (4).

Kara H., T. Tiryaki and C. Yüksel (2014), "In Search of a Reasonable Credit Growth Rate for Turkey," Central Bank Review 14 (1).

Manpower (2019), Closing the Skills Gap: What Workers Want, ManPowerGroup.

McKinsey (2020), The future of work: Turkey's Talent Transformation in the Digital Era, McKinsey Global Institute.

Mulier Life (2020), Kearney: Turkey will be the star of the post-19 Covidien world.

Ministry of Treasury and Finance (2020), Debt Indicators.

Ministry of Development (2018), Saglik Hizmet Kalitesi ve Mali Surdurulebilirlik, 11th Development Plan (2019-2023), Report of the Special Commission.

Ministry of Treasury and Finance (2020), New Economy Programme 2021-2023.

Mimir, Y. and E. Sunel (2019), "External Shocks, Banks, and Optimal Monetary Policy: A Recipe for Emerging Market Central Banks", International Journal of Central Banking, Vol. 15/2, pp. 235-299,

Nguyen, H., T. Taskin and A. Yilmaz (2017),"Resource Misallocation in Turkey", World Bank Policy Research Working Paper, No. 7780.

Niellson, U. (2013),"Do less regulated markets attract lower quality firms? Evidence from the London AIM Market", Journal of Financial Intermediation, Vol. 22 (2013).

OECD (2012), Recommendation of the Council on Regulatory Policy and Governance, OECD Publishing, Paris.

OECD (2013), Supporting Investment in Knowledge Capital, Growth and Innovation, OECD Publishing, Paris.

OECD (2015), Taxation of SMEs in OECD and G20 Countries, OECD Tax Policy Studies, No. 23, OECD Publishing, Paris.

OECD (2015b), Opportunities and Constraints of Market-Based Financing for SMEs, OECD Report to G20 Finance Ministers and Central Bank Governors.

OECD (2016), OECD Economic Surveys: Turkey 2016, OECD Publishing, Paris.

OECD (2017),"Enhancing The Contributions of SMEs in a Global and Digitalised Economy", Meeting of the OECD Council at Ministerial Level, Paris 2017.

OECD (2018a), OECD Economic Surveys: Turkey 2018, OECD Publishing, Paris.

OECD (2018b), Good Jobs for All in a Changing World of Work, OECD Publishing, Paris.

OECD (2019a), SME and Entrepreneurship Outlook 2019, OECD Publishing, Paris.

OECD (2019b), “R\&D Tax Incentives: Turkey, 2019”, (Link) Directorate for Science, Technology and Innovation, December 2019.

OECD (2019c), OECD Pensions Outlook, OECD Publishing, Paris.

OECD (2020a), "Corporate sector vulnerabilities during the Covid-19 outbreak: assessment and policy responses", Tackling Coronavirus Series.

OECD (2020b), "Insolvency and debt overhang following the COVID-19 outbreak: assessment of risks and policy responses", Tackling Coronavirus Series, forthcoming.

OECD (2021), OECD Economic Surveys: Turkey 2021, OECD Publishing, Paris.

OECD/ETF/EU/EBRD (2019), "SME Policy Index: Western Balkans and Turkey 2019: Assessing the Implementation of the Small Business Act for Europe", SME Policy Index, OECD Publishing, Paris. 
Özçelik, E. and E. Taymaz (2008),"R\&D support programmes in developing countries: The Turkish experience", Research Policy, Vol. 37 (2).

Ozdamar, M., B. Tanyeri and L. Akdeniz (2020),"The effect of tax regulation on firm value: the Turkish case of Allowance for Corporate Equity (ACE) regulation", Applied Economics Letters.

Özlale, Ü. and B. Polat (2019),"Understanding Firm Dynamics and Job Creation In Turkey Using the Entrepreneur Information System Database", Working Paper No: 2019-2, TÜSIAD - Sabancı Üniversitesi Rekabet Forumu.

OECD (2020), OECD Economic Surveys: Costa Rica 2020, OECD Publishing, Paris.

OECD (2019), Pensions at a Glance 2019: OECD and G20 Indicators,

OECD (2019), OECD leading multilateral efforts to address tax challenges from digitalisation of the economy.

OECD (2018), Latin American and Caribbean Competition Forum - Session I: The Informal Economy in Latin America and the Caribbean: Implications for Competition Policy, Background Note,

OECD (2020), Job retention schemes during the COVID-19 lockdown and beyond, Tackling Coronavirus (COVID-19)

OECD (2020), OECD Code of Liberalisation of Capital Movements,

OECD (2020), Capacity for remote working can affect lockdown costs differently across places,

OECD Policy Responses to Coronavirus (COVID-19),

OECD (2019), From promises to action: Addressing discriminatory social institutions to accelerate gender equality in $\mathrm{G} 20$ countries, OECD Development Center,

OECD (2020), OECD Employment Outlook 2020: Worker Security and the COVID-19 Crisis, OECD Publishing, Paris.

OECD (2020), The OECD Jobs Strategy: Implementation Highlights for Korea.

OECD (2019), OECD Environmental Performance Reviews: Turkey 2019, OECD Environmental

Performance Reviews, OECD Publishing, Paris.

OECD (1997), Convention on Combating Bribery of Foreign Public Officials in International Business Transactions, OECD Publishing, Paris.

OECD (2019), Turkey's foreign bribery enforcement framework needs to be urgently strengthened and corporate liability legislation reformed, OECD Publishing, Paris.

OECD (2018), OECD Strategic Approach to Combating Corruption and Promoting Integrity, OECD Publishing, Paris.

Ozatay, F. (2019), "Mind the Gap: Debt Limit and Fiscal Stimulus Debt Limit", Working Paper, No. 201901, TOBB University,

Ortayli N. (2020), "Biz Uykudan Uyanmazsak Salgin Bizi Terketmeyecek", Yetkin Report

Özmen U. (2019) "Econoic Complexity and Sovereign Risk Premia”, Economics Bulletin, Vol (39) 3.

Presidency of Strategy and Budget (2019), Eleventh Development Plan 2019-2023, Presidency of the Republic of Turkey.

PwC (2016), "Turkish NPL Purchasing Market: Overview and the way forward", (Link). [Last access: 10 August 2020].

PwC (2017), "Transformation of the Asset Management Industry in Turkey", (Link) [Last access: 17 September 2020].

Randall, S.J. and M. Kim (2014),"Promoting The Financing of SMEs and Start-ups in Korea", OECD Economics Department Working Paper, No. 1162.

Reuters (2019), Turkey must step up measures against money laundering, watchdog says, 
v. Rooij, M., A. Lusardi, and R. Alessie (2011),"Financial literacy and stock market participation", Journal of Financial Economics, Vol. 101 (2).

Schoar, A. (2010),"The Divide between Subsistence and Transformational Entrepreneurship", in: Innovation Policy and the Economy, edited by J. Lerner and S. Stern, pp. 57-81, National Bureau of Economic Research.

Sayan S. (2020), "Cari açık ilelebet payidar kalacak mı?”, TEPAV Arastirma Notu.

Sak G. and F. Özatay (2020), "What If Turkey Imposes a Curfew Due To COVID-19 ? », TEPAV Arastirma Notu.

Tarman, B. and M.F. Yigit (2010),"Turkish economy and vocational education system: Regressive or progressive?", Conference Paper: 54 ${ }^{\text {th }}$ CIES Annual Conference: Remanaging Education.

Taymaz, E. and K. Yilmaz (2007),"Productivity and trade orientation: Turkish manufacturing industry before and after the custom union", Journal of International Trade and Diplomacy, Vol. 1.

Tukel H. (2020), "COVID 19 ve Türkiye'de İş Piyasası”, SEDEFED Uzman Görüşü Notu, October. (Link)

World Bank (2014),"Evaluation of the EU - Turkey Customs Union", Report No. 85830-TR.

World Bank (2019a), Firm Productivity and Economic Growth in Turkey, Productivity Report 2019, Washington.

World Bank (2019b), Leveraging Digital Financial Solutions To Promote Formal Business Participation, The World Bank Group, Washington.

World Bank (2019c),"Growth in the Shadow - Challenges of Informality", Global Economic Prospects, Chapter 3.

World Bank (2020),"COVID-19 Outbreak: Implications on Corporate and Individual Insolvency", COVID19 Notes Finance Series, World Bank Group.

WTO (2019), Global Value Chain Development Report 2019: Technological Innovation, Supply Chain Trade, And Workers in a Globalized World, WTO, Lausanne.

World Justice Project (2019), Rule of Law Index 2019. (Link)

Yarba, I., Z. N. Güner (2019),"Leverage dynamics: Do financial development and government leverage matter? Evidence from a major developing country", Empirical Economics, May 2019. 


\section{Appendix 1. Unleashing the full potential of the Turkish business sector}

\section{Measuring the speed of resource allocation}

Allocative efficiency is measured using a reduced-form empirical model based on Turkish firmlevel data from the EIS database (see Box 2). The sample is restricted to manufacturing sectors and the 2006-2017 period. The empirical model denoted in equation 1, similar to the model of Adalet McGown et al. (2018), Decker et al. (2018) and OECD (2018c), is estimated. All estimations presented in this box were carried out in close co-operation with the structural analysis department of the Turkish Central Bank.

$N$

$$
\Delta \ln L i_{,}=\sum \beta_{s} * D_{s} * \ln L P_{i, s, t-1}+\theta X_{i, s, t-1}+\gamma_{s, t}+\epsilon_{i, s, t}
$$

where $\Delta l n L_{i, s, t}$ represents employment growth of firm - $i$ in manufacturing sector $s$ at time. $L P$ stands for the labour productivity, measured by real value added over total employment, $D_{s}$ is a dummy variable that allows to obtain different elasticities for different subsets of the firm sample, for example for firms in different subsectors or for different age groups. $X$ is the matrix of firm-level control variables. The model accounts for differences in firm sizes and export activity with lagged logarithm of the level of employment and a dummy if the firm exported in $t-1$. Firm age is also controlled for to take different firm dynamics across the life-cycle of firms into account. , denotes for the sector-year fixed effects and control for any unobserved time-varying industry specific determinants of employment growth. Most importantly, $\beta_{s}$ parameters provide a measure of dynamic allocative efficiency. Intuitively, $\beta_{s}$ measures how swiftly labour flows to firms that were productive in the year before.

The model is estimated for two periods to gauge whether allocative efficiency may has changed over time. As robustness checks, the model is further estimated for all manufacturing firms within subsectors according to a 2- and 4-digit classification and for a definition of labour productivity based on real value added and total revenue. Tabulated results for the robustness checks can be found below. The model appears well-behaved and estimated cofficients are in line with expectations. The negative sign of the dummy for exporters may appear counter-intuitive. However, it should be noted that this the model captures high productivity firms also through the lagged level of labour productivity. Thus, the dummy for exporting activity should not be interpreted as reflecting higher productivity firms. 
Table 1.1. Allocative efficiency in Turkish manufacturing sectors: Firm-level results

\begin{tabular}{|c|c|c|c|c|}
\hline Dependent variable: Growth in employment & (1) & (2) & (3) & (4) \\
\hline & $\begin{array}{c}\text { 2-digit } \\
\text { 2006-2017 }\end{array}$ & $\begin{array}{c}\text { 2-digit } \\
\text { 2010-2017 }\end{array}$ & $\begin{array}{c}\text { 4-digit } \\
2006-2017\end{array}$ & $\begin{array}{c}\text { 4-digit } \\
\text { 2010-2017 }\end{array}$ \\
\hline \multirow[t]{2}{*}{ Log(Labour Productivity) (t-1) } & $0.0612^{* * *}$ & $0.0606^{* * *}$ & $0.0609^{\star * \star}$ & $0.0608^{\star * *}$ \\
\hline & $(0.0021)$ & $(0.0025)$ & $(0.0021)$ & $(0.0025)$ \\
\hline \multirow[t]{2}{*}{ Age (t-1) } & $-0.0150^{\star * *}$ & $-0.0149^{* * *}$ & $-0.0149^{* * *}$ & $-0.0148^{* * *}$ \\
\hline & $(0.0004)$ & $(0.0005)$ & $(0.0004)$ & $(0.0005)$ \\
\hline \multirow[t]{2}{*}{ Dummy exporter (t-1) } & $-0.0209^{\star * *}$ & $-0.0216^{\star * *}$ & $-0.0205^{\star * *}$ & $-0.0210^{* * *}$ \\
\hline & $(0.0029)$ & $(0.0035)$ & $(0.0030)$ & $(0.0035)$ \\
\hline \multirow[t]{2}{*}{ Constant } & $-0.5318^{* * *}$ & $-0.5061^{* * *}$ & $-0.5290^{* * *}$ & $-0.5091^{* * *}$ \\
\hline & $(0.0220)$ & $(0.0264)$ & $(0.0223)$ & $(0.0268)$ \\
\hline Obs. & 127,951 & 85,902 & 127,951 & 85,902 \\
\hline Adj. R-Squared & 0.035 & 0.035 & 0.043 & 0.042 \\
\hline
\end{tabular}

HAC robust standard errors in parentheses. All models include firm-level fixed effects, dummies for each year and a control for lagged investment. ${ }^{* / *}{ }^{* * *}$ denotes significance at the $10 \% / 5 \% / 1 \%$ level.

A comparison of allocative efficiency over time suggests that the allocation of labour in Turkish manufacturing sectors slightly declined. However, the differences in the elasticities of employment growth to past productivity are not significantly different from a statistical point of view. Other studies found, however, support for a more a slowdown in allocative efficiency (Nguyen et al., 2017).

\section{Turkey has a wide range of business support measures in place}

\section{General Investment Incentive Scheme}

Investment projects across all regions, which are above a certain size threshold, are eligible for the set of support measures specified in Table 1. 2. The size thresholds vary across regions.

The minimum amount of a fixed investment project in region 1 and 2 is TRY 1 Million, and TRY 500 thousands for all other regions. Investment projects excluded from the investment incentive programme are not eligible for support from the General Investment Incentive Scheme.

\section{Regional Investment Incentive Scheme}

The size thresholds for eligible investments under the Regional Investment Incentive Schemes are the same as for the General Investment Incentive Scheme.

The terms and rates of support within the Regional Investment Incentive Scheme vary by region and whether the investment is made within an organized industrial zone (OIZ) or specialized industrial zones (IZ).

The amount of investment eligible for a reduced corporate income tax rate (measure 3 from Table 1.2) is $15 \%$ outside OIZ or IZ zones in region 1 and goes up steadily by $5 \mathrm{pp}$. until $50 \%$ for the same investment in region 6 . Within OIZ or $\mathrm{IZ}$ zones, the amount for which reduced corporate tax rates apply are $20 \%$ (region 1 ) to $55 \%$ (region 6 ).

The support period for employer's part of the social security premium (measure 4) outside OIZ or IZ zones is 2 (region 2 ) to 10 years (region 6 ) and 3 to 12 years within $\mathrm{OIZ}$ or IZ regions. 
The support period for the social security premium for employees (measure 6) and the income tax withholding (measure 5) support comprises only investments in region 6 and amounts to 10 years.

For regions 3-6, the Ministry of Industry and Technology covers 3 to $7 \mathrm{pp}$. of the interest payments on certain local currency loans eligible under the Interest/Profit Share support (measure 7). For loans in foreign currency, the corresponding rates are $1 \mathrm{pp}$. for region 3 and 4 and $2 \mathrm{pp}$. for region 5 and 6 .

\section{Priority Investment Incentive Scheme}

The Priority Investment Incentive Scheme comprises a pre-determined set of investment projects categorized as priorities. Any investment within this list gets support as if it is undertaken in region 5 , even if the actual investment falls into region 1-4. The list spans over various industrial sectors and product groups. A full list can be found in the appendix.

The corporate income tax rate (measure 3) within this investment scheme is reduced by to $80 \%$. The amount of investment eligible for the deduction equals $40 \%$. The deduction, however, only applies to investment within the scope of incentive certificates issued for certain manufacturing sectors.

The period for which the Ministry of Industry and Technologytakes over the employer's share of the social security (measure 4) payments is 7 years.

The Ministry of Industry and Technology covers $5 \mathrm{pp}$. of the interest payments on local currency loans eligible under the Interest/Profit Share support (measure 7) and 2 pp. on loans in foreign currency.

Strategic Investment Incentive Scheme

This scheme intends to support the production of intermediate and final products with a high degree of import dependence to contribute to the reduction of the current account deficit. Further, it encourages high-tech and high value added investments in order to boost Turkey's international competitiveness.

The strategic investment incentive scheme supports investments that fulfil the four criteria listed below. Moreover, any investment approved by the Ministry of Trade and Technology within the Technology Focused Industry Movement Program (TFIMP) also fall under the strategic investment incentive scheme.

1. to be made for production of intermediate and final goods with high import dependence of which more than $50 \%$ of these goods are supplied by imports,

2. to have a minimum investment amount of 50 million $\mathrm{TL}$,

3. to create minimum $40 \%$ value added (This condition is not applicable to refined petroleum production investments and petrochemicals production investments),

4. to have an import amount of at least $\$ 50$ million for goods to be produced in the last one year period (This condition is not applicable to goods with no domestic production) (MolT)

The period for which the Ministry of Industry and Technologytakes over the employer's share of the social security (measure 4) payments is 7 years but 10 years for region 6 . The period for the employee's share (measure 6 ) equals 10 years, is, however, restricted to investments in region 6 and strategic investments under the TFIMP program.

The Ministry of Industry and Technologycovers $5 \mathrm{pp}$. of the interest payments on local currency loans eligible under the Interest/Profit Share support (measure 7) and $2 \mathrm{pp}$. on loans in foreign currency. Higher shares apply to investment projects that fall under the TFIMP program.

The support period for the income tax withholding (measure 5) support comprises only investments in region 6 or in any region if covered by the TFIMP program and amounts to 10 years. 
Table 1.2. Support measures

\begin{tabular}{|c|c|c|c|c|}
\hline & $\begin{array}{l}\text { General Investment } \\
\text { Incentive Scheme }\end{array}$ & $\begin{array}{l}\text { Regional Investment } \\
\text { Incentive Scheme }\end{array}$ & $\begin{array}{l}\text { Priority Investment } \\
\text { Incentive Scheme }\end{array}$ & $\begin{array}{l}\text { Strategic Investment } \\
\text { Incentive Scheme }\end{array}$ \\
\hline 1 VAT Exemption & $x$ & $x$ & $x$ & $x$ \\
\hline 2 Customs Duty Exemption & $x$ & $x$ & $x$ & $x$ \\
\hline $\begin{array}{l}3 \text { Reduced corporate income } \\
\text { tax rate }\end{array}$ & & $x$ & $x$ & $x$ \\
\hline $\begin{array}{l}4 \text { Social Security Premium } \\
\text { Support (employer) }\end{array}$ & & $x$ & $x$ & $x$ \\
\hline $\begin{array}{l}5 \text { Income Tax Withholding } \\
\text { Support }\left(^{*}\right)\end{array}$ & $x$ & $x$ & $x$ & $x$ \\
\hline $\begin{array}{l}6 \text { Social Security Premium } \\
\text { Support (employee) }\left(^{\star}\right)\end{array}$ & & $x$ & $x$ & $x$ \\
\hline $\begin{array}{l}7 \text { Interest/Profit Share Support } \\
\left({ }^{\star \star}\right)\end{array}$ & & $x$ & $x$ & $x$ \\
\hline 8 Land Allocation & & $x$ & $x$ & $x$ \\
\hline 9 VAT Refund $\left({ }^{* * *}\right)$ & & & & $x$ \\
\hline
\end{tabular}

Notes: $\left({ }^{*}\right)$ Provided that the investment is made in region 6 and the strategic investments that are supported within the Technology Focused Industry Movement Program (TFIMP). $\left.{ }^{* \star}\right)$ Provided that the investment is made in the regions $3,4,5$ or 6 within the framework of the Regional Investment Incentive Scheme. $\left.{ }^{* * *}\right)$ For strategic investments with a minimum fixed investment amount of TRY 500 million.

\section{Support measures}

VAT exemption refers to an exemption on VAT of imported and/or locally provided investment machinery and equipment. In addition, selling and renting of intangible rights and software within the scope of the investment encouragement certificate also qualify for VAT exemption. The Customs Duty Exemption exempts investments in imported machinery and equipment from customs duty within the scope of the investment incentive certificate. Tax Deduction denotes a deduction scheme in which income or corporate tax is calculated based on reduced rates until the total tax due reaches a certain amount of the initial investment. The Social Security Premium Support (employer) refers to a subsidy where the Ministry of Treasury and Finance takes over the employer's share of social security up to wage corresponding to the legal minimum wage for any additional employment created by a new investment project. The Income Tax Withholding Allowance withholds income taxes for any additional employment created by a new investment project within the scope of the pre-defined investment encouragement certificate. This allowance is only eligible to investments in region 6 and strategic investments supported under the TFIMP within the scope of an investment incentive certificate. In the Social Security Premium Support (employee) the Ministry of Industry and Technology takes over the employee's share of social security premiums up to wage equal to the legal minimum wage for any new job created through a new investment project. This subsidy is restricted to investments in region 6 and strategic investments supported under the TFIMP within the scope of an investment incentive certificate. The Interest/Profit Share Support refers to a subsidy, where the Ministry of Industry and Technologycovers a prespecified share of interest payment of a loan with a maturity greater than one year up to a total loan amount of $70 \%$ of amount invested. This subsidy only supports investments within the scope of an investment encouragement certificate. The Land Allocation refers to a scheme where land is allocated to investment within the Investment Incentive Certificate, according to rules and principles determined by the Ministry of Industry and Technology. The VAT Refund denotes a refund on VAT on expenses made on buildings and construction if the investment is a strategic investment. 
Table 1.3. Categorization of Turkish provinces to regions under the investment support programmes

\begin{tabular}{l|l|l|l|l|l}
\hline \multicolumn{1}{|c|}{ Region 1 } & \multicolumn{1}{|c|}{ Region 2 } & \multicolumn{1}{|c|}{ Region 3 } & \multicolumn{1}{c|}{ Region 4 } & \multicolumn{1}{c}{ Region 5 } & \multicolumn{1}{c}{ Region 6 } \\
\hline Ankara & Adana & Balıkesir & Afyonkarahisar & Adıyaman & Ağrı \\
\hline Antalya & Aydın & Biecik & Amasya & Aksaray & Ardahan \\
\hline Bursa & Bolu & Burdur & Artvin & Bayburt & Batman \\
\hline Eskişehir & Çanakkale & Gaziantep & Bartın & Çankırı & Bingöl \\
\hline İstanbul & Denizli & Karabük & Çorum & Erzurum & Bitlis \\
\hline İzmir & Edirne & Karaman & Düzce & Giresun & Dizarbakır \\
\hline Kocaeli & Isparta & Mainsa & Elazı̆ & Gümüşhane & Hakkari \\
\hline Muğla & Kayseri & Mersin & Erzincan & Kahramanmaraş & Iğdır \\
\hline & Kırklareli & Samsun & Hatay & Kilis & Kars \\
\hline & Konya & Trabzon & Kastamonu & Niğde & Mardin \\
\hline & Sakarya & Uşak & Kırıkkale & Ordu & Muş \\
\hline & Tekirdağ & Zonguldak & Kırşehir & Osmaniye & Sirrt \\
\hline & Yalova & & Kütahya & Sinop & Şanlıurfa \\
\hline & & Malatya & Tokat & Şırnak \\
\hline & & & Nevşehir & Tunceli & Van \\
\hline & & & Rize & Yozgat & \\
\hline & & & Sivas & & 11 provinces \\
\hline
\end{tabular}

\section{The cost of capital of listed firms in Turkey}

The cost of capital denotes the rate of return an investor requires to engage in an investment project. Higher values imply that investors ask for a higher return to be compensated with the riskiness of the associated project. The cost of capital consists of the cost of debt and the cost of equity. The cost of debt can be inferred from firms' balance sheets. Following Frank and Shen (2016) and Drobetz et al. (2019), it is calculated as $K_{d e b t}=L E V \times(1-T A X) \times i$, where $L E V$ denotes a firm's leverage, i.e. total debt over total assets, $T A X$ is the firm's corporate tax rates and $i$ the average interest expense of the firm, calculated as interest expense over net income. The cost of debt is thus the interest paid by the firm. The cost of equity requires a model of the ex-ante cost of equity capital. The standard approach (e.g. Frank and Shen (2016) and Drobetz et al. (2019)) relies on earnings forecasts' of financial analysts, which are then used to infer the internal rate of return that equates today's earnings per share the forecasted values. In particular, the analyses uses a one-period Gordon Growth model with one-year ahead forecasted earnings from the IBES database to provide an estimate of the cost of equity.

A simple reduced-form investment model underlines that higher ex-ante cost of capital is associated with less investment. The model relies on firm-level balance sheet data for the period from 2012-2018. The country sample consists of Chile, Spain, Israel, Italy, Mexico, Poland, Portugal and Turkey. The investment model controls for firmlevel cash-flow, a measure for liquidity, but also for inflation, GDP growth and rule of law. Firm fixed effects control for all unobserved time-invariant heterogeneity at the firmlevel. The results show that in the employed sample, cost of capital is significantly negatively associated to investment. The estimated coefficient imply that a one standard deviation decrease of cost of debt lead an increase of the investment of $1.3 \%$. 
Table 1.4. Cost of capital and firm-level investment

\begin{tabular}{|c|c|c|c|c|}
\hline $\begin{array}{l}\text { Dependent variable: } \\
\text { Investment / total assets }\end{array}$ & (1) & (2) & (3) & (4) \\
\hline \multirow[t]{2}{*}{ Cash Flow / Total Assets } & $0.7482^{* * *}$ & $0.7485^{\star \star *}$ & $0.6749^{\star \star *}$ & $0.6750^{* * *}$ \\
\hline & $(0.0068)$ & $(0.0068)$ & $(0.0075)$ & $(0.0075)$ \\
\hline \multirow[t]{2}{*}{ Cost of debt } & $-0.0339 * * *$ & $-0.0336^{\star \star \star}$ & $-0.0428^{\star * *}$ & $-0.0428^{\star * *}$ \\
\hline & $(0.0059)$ & $(0.0059)$ & $(0.0068)$ & $(0.0068)$ \\
\hline \multirow[t]{2}{*}{ Cost of equity } & $-0.0593^{* * *}$ & $-0.0594^{* * *}$ & $-0.0583^{* * *}$ & $-0.0581^{* * *}$ \\
\hline & $(0.0057)$ & $(0.0057)$ & $(0.0058)$ & $(0.0058)$ \\
\hline \multirow[t]{2}{*}{ Inflation } & & $0.0020^{*}$ & & 0.0019 \\
\hline & & $(0.0012)$ & & $(0.0014)$ \\
\hline \multirow[t]{2}{*}{ GDP growth } & & $0.0026^{\star \star *}$ & & $0.0025^{\star *}$ \\
\hline & & $(0.0010)$ & & $(0.0012)$ \\
\hline \multirow[t]{2}{*}{ Rule of law } & & -0.0223 & & 0.0032 \\
\hline & & $(0.0160)$ & & $(0.0185)$ \\
\hline \multirow[t]{2}{*}{ Constant } & $-0.0038^{* * *}$ & -0.0054 & 0.0025 & -0.0103 \\
\hline & $(0.0014)$ & $(0.0095)$ & $(0.0016)$ & $(0.0110)$ \\
\hline Firm FE & Y & Y & $\mathrm{N}$ & $\mathrm{N}$ \\
\hline Country FE & $\mathrm{N}$ & $\mathrm{N}$ & Y & Y \\
\hline Industry FE & $\mathrm{N}$ & $\mathrm{N}$ & Y & Y \\
\hline Year FE & Y & $Y$ & Y & $\mathrm{Y}$ \\
\hline Observations & 3,917 & 3,917 & 3,934 & 3,934 \\
\hline Adj. R2 & 0.826 & 0.826 & 0.758 & 0.758 \\
\hline
\end{tabular}

Note: Clustered standard errors in parentheses. ${ }^{* / *}{ }^{* * * *}$ denotes significance at the $10 \% / 5 \% / 1 \%$ level.

The cost of capital of Turkish listed firms from non-financial sectors is above the cost of capital of listed firms in peer countries (Figure 17). In 2018, the cost of capital was around 16\%, significantly higher than in peer countries. The estimated cost of equity of Turkish non-financial listed firms was higher than in peer countries, though with around $8.6 \%$ only slightly higher than the cost of equity of Polish firms. While financial leverage and investment rates of Turkish firms are comparable to firms in peer countries, the high cost of capital points to factors independent of firms' balance sheets. 
Table 1.5. Drivers of cost of capital at the aggregate level

\begin{tabular}{|c|c|c|c|c|c|c|}
\hline & $(1)$ & (2) & (3) & (4) & (5) & (6) \\
\hline & Cost of debt & Cost of debt & Cost of debt & Cost of equity & Cost of equity & Cost of equity \\
\hline \multirow[t]{2}{*}{ GDP growth } & -0.0002 & & & $-0.0015^{\star}$ & & \\
\hline & $(0.0002)$ & & & $(0.0008)$ & & \\
\hline \multirow[t]{2}{*}{ Inflation } & $0.0005^{* *}$ & & & -0.0002 & & \\
\hline & $(0.0002)$ & & & $(0.0009)$ & & \\
\hline \multirow[t]{2}{*}{ Trade / GDP } & -0.0001 & & & 0.0000 & & \\
\hline & $(0.0001)$ & & & $(0.0003)$ & & \\
\hline \multirow[t]{2}{*}{$\begin{array}{l}\text { Current Account } \\
\text { Balance / GDP }\end{array}$} & 0.0001 & & & $-0.0018^{*}$ & & \\
\hline & $(0.0002)$ & & & $(0.0009)$ & & \\
\hline \multirow[t]{2}{*}{ Rule of Law } & $-0.0043^{*}$ & & & $-0.0082^{*}$ & & \\
\hline & $(0.0026)$ & & & $(0.0128)$ & & \\
\hline \multirow[t]{2}{*}{ Marketcap / GDP } & & 0.0000 & & & $-0.0004^{\star *}$ & \\
\hline & & $(0.0000)$ & & & $(0.0002)$ & \\
\hline \multirow[t]{2}{*}{ Non-performing loans } & & -0.0002 & & & $-0.0022^{\star \star *}$ & \\
\hline & & $(0.0002)$ & & & $(0.0007)$ & \\
\hline \multirow[t]{2}{*}{ Bank capital / GDP } & & $-0.0014^{* *}$ & & & -0.0020 & \\
\hline & & $(0.0006)$ & & & $(0.0023)$ & \\
\hline \multirow[t]{2}{*}{ Inward FDI / GDP } & & $-0.0003^{*}$ & & & 0.0008 & \\
\hline & & $(0.0002)$ & & & $(0.0007)$ & \\
\hline \multirow[t]{2}{*}{ Std.Dev. Stock Returns } & & & 0.2126 & & & 0.3729 \\
\hline & & & $(0.1267)$ & & & $(0.4988)$ \\
\hline \multirow[t]{2}{*}{ Std. Dev. Foreign exchange } & & & $0.6846^{\star \star *}$ & & & 0.4642 \\
\hline & & & $(0.1735)$ & & & $(0.6829)$ \\
\hline \multirow[t]{2}{*}{ CDS Spread } & & & 0.0000 & & & $0.0001^{* * *}$ \\
\hline & & & $(0.0000)$ & & & $(0.0000)$ \\
\hline \multirow[t]{2}{*}{ Constant } & $0.0154^{* * *}$ & $0.0218^{* * *}$ & 0.0003 & $0.0544^{* * *}$ & $0.0955^{\star * *}$ & $0.0461^{* \star *}$ \\
\hline & $(0.0037)$ & $(0.0048)$ & $(0.0016)$ & $(0.0185)$ & $(0.0194)$ & $(0.0062)$ \\
\hline Observations & 63 & 49 & 54 & 63 & 49 & 54 \\
\hline R-squared & 0.7820 & 0.5988 & 0.8117 & 0.8712 & 0.8990 & 0.9254 \\
\hline Adj. R2 & 0.686 & 0.398 & 0.730 & 0.814 & 0.849 & 0.893 \\
\hline
\end{tabular}

Note: Clustered standard errors in parentheses. ${ }^{* / *} /{ }^{* \star *}$ denotes significance at the $10 \% / 5 \% / 1 \%$ level.

To shed light on potential macroeconomic drivers, the firm-level measures of cost of capital are aggregated to the country-level by taking the median value per country and year. Before the aggregation, cost of capital is cleaned for firm-level leverage and differences across industries. The simple regressions on pre-determined macroeconomic variables, implemented by regressing on lagged values covariates show that cost of debt is negatively correlated with GDP growth and rule of law. Higher inflation is positively correlated with cost of debt. Similarly, larger values of bank capital over total bank assets are associated negatively with cost of debt, whereas exchange rate volatility and CDS spreads show a positive correlation. Higher growth, better rule of law and more developed equity markets reduce cost of equity according to the correlations shown above, while higher CDS rates increase cost of equity. 